Türkiye Jeoloji Bülteni
Geological Bulletin of Turkey
$60(2017) 589-614$
doi:10.25288/tjb.370618

\title{
Bağlararası Höyüğü Çevresinde Paleocoğrafya ve Jeoarkeoloji Araştırmaları (Çeşme- İzmir)
}

Paleogeography and Geoarcheology Researches in Surroundings of the Bağlararası Mound (Çeşme-İzmir)

\author{
Serdar Vardar1, " $\mathbb{D}$, Ertuğ Öner² $\mathbb{D}$, Rifat İlhan² $\mathbb{E}$ \\ ${ }^{1}$ İzmir Kâtip Çelebi Üniversitesi, Sosyal ve Beşeri Bilimler Fakültesi, Coğrafya Bölümü, \\ Balatcı, Çiğli, İzmir \\ ${ }^{2}$ Ege Üniversitesi, Edebiyat Fakültesi, Coğrafya Bölümü, Bornova, İzmir
}

Geliş/Received : 31.08.2017 • Düzeltilmiş Metin Geliş/Revised Manuscript Received : 13.12.2017 • Kabul/Accepted : 15.12 .2017 • Bask1/Printed : 29.12 .2017 Araştırma Makalesi/Research Article Türkiye Jeol. Bül. / Geol. Bull. Turkey

Öz: Anadolu'nun Ege kıyıları çağlar boyunca uygun toplumsal yaşam için coğrafi koşullara sahip olmuştur ve yaşam için elverişli alanlar olarak ortaya çıkmıştır. Bunlardan biri de Çeşme yöresidir. Bu dönemlerde kıyılarda liman kentleri olarak kurulan eski yerleşmeler, giderek kıyı çizgisinden oldukça içerilerde kalmış ve önemlerini kaybetmişler, çoğu terk edilmiştir. Çeşme Bağlararası kazı alanlarındaki MÖ 2. bin ve 3. bin yerleşmelerinin Tunç Çağı'na ait olduğu ve o dönemde doğal çevrenin bugünden çok farklı olduğu anlaşılmaktadır. Çeşme Bağlararası düzlüğü, Liman Deresi'nin alüvyonlarıyla ve daha çok yamaç sellerinin kolüvyal sedimanlarıyla dolmuş KB-GD doğrultulu bir tektonik çöküntünün tabanıdır. Oldukça küçük bir drenaj havzasına sahip olan Liman Deresi, Çeşme Garajı'ndan başlayarak, KB yönünde limana kadar yaklaşık $600 \mathrm{~m}$ uzanan ve $500 \mathrm{~m}$ eninde sığ bir kıyı çukurluğunu doldurmuştur. Tarihsel doğal çevre değişmelerinin izleri çöküntüyü dolduran bu tortul katmanlarda gizlidir. Bu nedenle, Bağlararası çevresinin paleocoğrafya özelliklerini belirlemek, kıyı çizgisi ve deniz seviyesi değişimlerini ortaya koyabilmek ve bazı arkeolojik sorulara cevap bulabilmek için Eylül (2016) ayında Bağlararası Höyüğü ve çevresinde 10 delgi sondaj gerçekleştirilmiştir. İlk bulgular, denizel dolguların ve kıyı-kıyı bataklığı-bataklık gibi geçiş ortamlarının yorumlarının fosil analizlerine dayanarak hassas yapılması gerekliliğini ortaya çıkarmıştır. Sondaj sonuçlarına göre birimlerin stratigrafisi, temelde Miyosen kiltaşı-kumtaşı anakayası üzerine uyumsuz olarak gelen Erken-Orta Holosen denizel çökelleri, Orta-Geç Holosen yaşlı höyük dolguları ve tüm birimleri örten yine OrtaGeç Holosen yaşlı alüvyal-kolüvyal dolgulardan oluşmaktadır. Alanda öncelikle denize daha yakın olan üçüncü bin yerleşiminin başlaması doğrudan Bronz Çağ regresyonu ile uyumlu görülmektedir. Bu regresyonun sonrasında ikinci bin yerleşiminin nispeten daha iç kesimlerde kurulduğu belirlenmiştir. Bunların yanında ilginç bir veri olarak, Santorini'deki Minoan volkanik patlamasına ait küller Bronz (Tunç) Çağı kültürel dolguları içinde bulunmuş, bunların element analizleri yapılmış ve kronostratigrafik yorumlarda kılavuz seviye olarak değerlendirilmiştir.

Anahtar Kelimeler: Bağlararası höyüğü, Çeşme, İzmir, jeoarkeoloji, paleocoğrafya

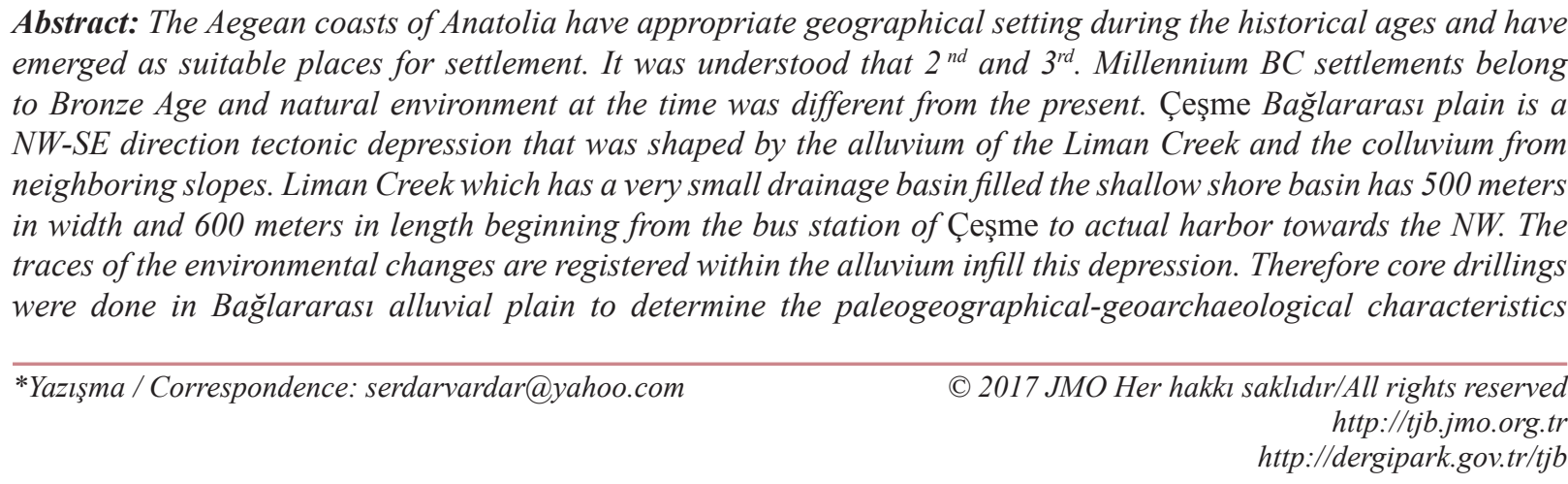


of the surroundings of the mound in order to detect the past coast line and sea level positions and answer the archaeological questions. 10 core drillings carried out at the September 2016 in the surroundings of the Bağlararasi mound. Grain size, hydrometer, calcimeter, microfossil and elemental analysis of drilling samples have been done. Preliminary results indicate that the interpretations of paleo-environments such as marine infills and coast-coastal swamp must be based on microfossil analysis and be done meticulously. According to results of the core drillings, Holocene stratigraphy of the fill can be identified in a chronostratigraphic order as: on the clay-sandstone basement is overlain by Holocene transgression fills (Early Holocene), coastal swamp (Middle Holocene), anthropogenic mound fills (Middle-Late Holocene) and alluvial-colluvial fills (Late Holocene). Starting of the $3^{\text {th }}$ millennium BC, the settlement was closer to the coast which is consistent with the Bronze Age regression. During the $2^{\text {nd }}$ Millennium $B C$, the settlement migrated inwards the land. The chemical analysis of a tephra layer, which is found within the cultural fills of the Bronze Age period, correlates well with the tephra emitted from Minoan volcanic eruption of Santorini. This layer is used as a key layer in chronostratigraphic interpretations.

Keywords: Bağlararası mound, Çeşme, geoarchaeology, İzmir, paleogeography

\section{GİRIŞ}

Coğrafya, insanlar ve doğal çevreleri ile aralarındaki etkileşimi inceleyen bir bilim alanıdır. İnsanlar, yerleşik yaşama geçişle birlikte coğrafi çevrelerinden etkilenmiş ve çevrelerini etkilemişlerdir. Arkeoloji, insan topluluklarının hayatlarını sürdürmek için ürettikleri her türlü alet, araç, yapı gibi materyalin (maddi varlığın, yapıtların) bugüne ulaşan kalıntılarını inceleyerek insanlığın kültürel geçmişini, değişimini ve gelişimini araştıran bir bilim alanıdır. Günümüzde bu amaçla yapılan çalışmalarda birçok bilim alanının katkılarından yararlanılmaktadır. "Jeoarkeoloji" adı altında toplanan bu katkıların önemli bir kısmını eski dönemlerdeki coğrafi çevre özelliklerinin belirlenmesi araştırmaları oluşturur. $\mathrm{Bu}$ araştırmalar, geçmişin coğrafyasını ifade eden "Paleocoğrafya" kavramı içinde değerlendirilir. $\mathrm{Bu}$ çalışmada, Holosen'de Batı Anadolu kıyılarımızdaki bazı antik yerleşmeler çevresinde meydana gelen doğal çevre değişmeleri ile ilgili bulgu ve değerlendirmelerimiz verilecektir. $\mathrm{Bu}$ amaçla bu kıyılarımızdaki alüvyal alanlarda delgi sondajlar ile çökel örnekleri alınarak, laboratuvarda sedimantolojik ve paleontolojik incelemeler yapılmış, çökelme alanlarının zaman içinde değişimleri belirlenmiştir. Tarihleme analizleri yapılabildiği ölçüde, bu değişmelerin zamanı da verilmiştir.

Son buzul çağında -130 metrelerde olan Dünya denizlerinin seviyesi, Orta Holosen'e kadar bugünkü seviyesine yükselmiş ve özellikle akarsu ağızlarına karşılık gelen alçak kıyılarda iç kesimlere sokulup koy ve körfezler oluşturmuştur. Orta Holosen'de deniz seviyesi yükselmesinin durmasiyla bu kez koy ve körfezler alüvyonlarla dolarak kıyı çizgisi deniz yönünde ilerlemiştir. $\mathrm{Bu}$ dönemlerde kıyılarda liman kentleri olarak kurulan eski yerleşmeler, giderek kıyı çizgisinden oldukça içerilerde kalmış ve önemlerini kaybetmişlerdir.

Çeşme ilçesi Bağlararası kazı alanı yukarıda sözü edilen deniz seviyesi değişimleri ile ilgili küresel eğilimleritestetmekiçin elverişlialanlardan biridir. Bu çalışmada Bağlararası Höyüğü Bronz (Tunç) Çağı antik yerleşimi civarında meydana gelen kıyı çizgisi değişmeleri ele alınmıştır. Çeşme Bağlararası mevkii günümüzdeki Marina alanına yakın yeni yapılaşmanın devam ettiği bir kıyı düzlügüdür. Marina'dan kıyı yoluna kadar olan kesim sonradan yapılmış bir dolgu alanıdır.

ÇeşmeBağlararasımevkiiÇeşmeMarinası'nın 50 m kadar kara tarafinda bulunmaktadır (Şekil 1). Bu mevkideki kazı alanı yerin ismi ile anılmakta ve Bağlararası olarak adlandırılmaktadır.

Bağlararası yerleşimi Minos uygarlığına ait izleri barındırdığı için arkeolojik olarak özel bir öneme sahiptir. Çeşme Bağlararası kazı alanlarındaki MÖ 2. bin ve 3. bin yıl yerleşmelerinin Tunç Çăğ'na ait olduğu ve o dönemde doğal çevrenin bugünden çok farklı olduğu anlaşılmaktadır (Şahoğlu vd. 2014). Söz konusu 
antik yerleşme, 2001 yılında İzmir ili, Çeşme ilçesinde, şehir merkezinde yer alan Bağlararası Mevkii'nde tesadüf eseri Çeşme Müzesi tarafından keşfedilmiştir. Çeşme Bağlararası arkeolojik kalıntıları gerekli önlemlerin anında alınması sayesinde yok olmaktan kurtulmuş, bunun ötesinde Anadolu arkeolojisi içinde çok az bilinen bir konunun da gün ışığına çıkmasını sağlamıştır.

2002-2005 yılları arasında Çeşme Arkeoloji Müzesi ile Ankara Üniversitesi Sualtı Arkeolojik Araştırma ve Uygulama Merkezi'nin (ANKÜSAM) ortak gerçekleştirdikleri bir kazı olan bu proje, Prof. Dr. Hayat Erkanal'ın bilimsel başkanlığında sürdürülmüştür. Üç yıllık bir aranın ardından 2009 yılından itibaren yeniden başlayan bu merkezdeki kazılar, ANKÜSAM faaliyetleri çerçevesinde Prof. Dr. Vasıf Şahoğlu başkanlığında sürdürülmektedir. Çeşme Bağlararası'nın yerleşim tarihi, şu ana kadar gerçekleştirilen çalışmalar ışığında günümüzden
4600 y1l kadar geriye gitmektedir. O dönemde, taş temelli kerpiç duvarlara sahip yapılarda yaşayan en eski Çeşmeliler, denizcilik ve tarımla uğraşmaktaydılar (http://ankusam.ankara.edu.tr/ cesme/).

Çeşme Bağlararası düzlüğü Liman deresinin alüvyonları ve daha çok yamaç sellerinin biriktirdiği kolüvyal sedimanlarla şekillenmiş bir tektonik çöküntü tabanıdır (Şekil 1, 2). KB-GD yönlü $600 \mathrm{~m}$ uzunlukta ve $500 \mathrm{~m}$ genişlikte olan depresyon tabanı, oldukça küçük bir su toplama alanına sahip olan Liman deresi tarafından (Çeşme Garajı'ndan başlayarak KB yönünde limana kadar) doldurmuştur. Çeşme limanı bu depresyonun KB kenarında denize açıldığı kesimdedir ve derinliği liman düzenlenmesinden önce 4 m'den azdır (Şekil 1). Liman düzenlemeleri sırasında koy tabanı derinleştirilerek ana kayaya ulaşılmış ve parçalanan dip dolgusunun atılması sonrasında 8-10 metre derinlik meydana gelmiştir.

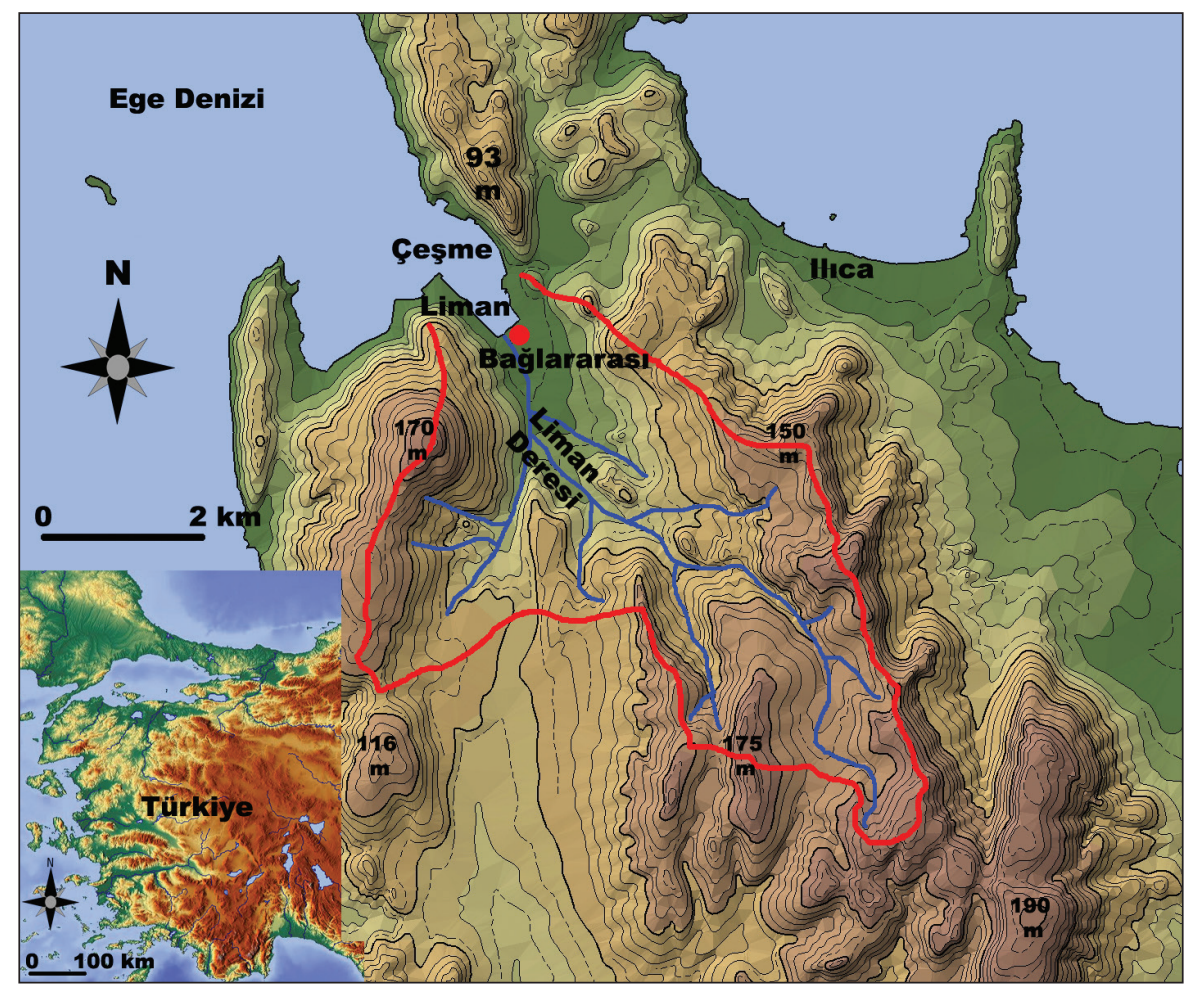

Şekil 1. Çeşme ve Bağlararası kazı alanı lokasyon haritası.

Figure 1. Location Map of Çeşme and Bağlararası Excavation Area 
Liman deresi depresyonunun batı kenarında 172 m ye kadar yükselen Karadağ tepesi Liman deresi havzasının en yüksek noktasıdır. Depresyon çevresindeki tepelerde anakaya olarak neritik kireçtaşları (Orta Triyas), Alt, Orta ve Üst Miyosen yaşlı karasal çökeller (kireçtaş1-marn-kiltaşı) dikkati çekmiştir. Bunun yanında havzanın iç kesimlerinde Miyosen yaşlı piroklastik kayalar ve andezit-dasit-riyolitler yüzeylemektedir (Şekil 2). Depresyonun uzanışı Batı Anadolu'nun KB-GD uzanımlı yapısal hatları ile büyük ölçüde uyumlu olup havzanın geneli KD-GB doğrultulu daha eski ve D-B doğrultulu daha genç kafesli tektonik zonları ile uyumludur (Kayan 1999).

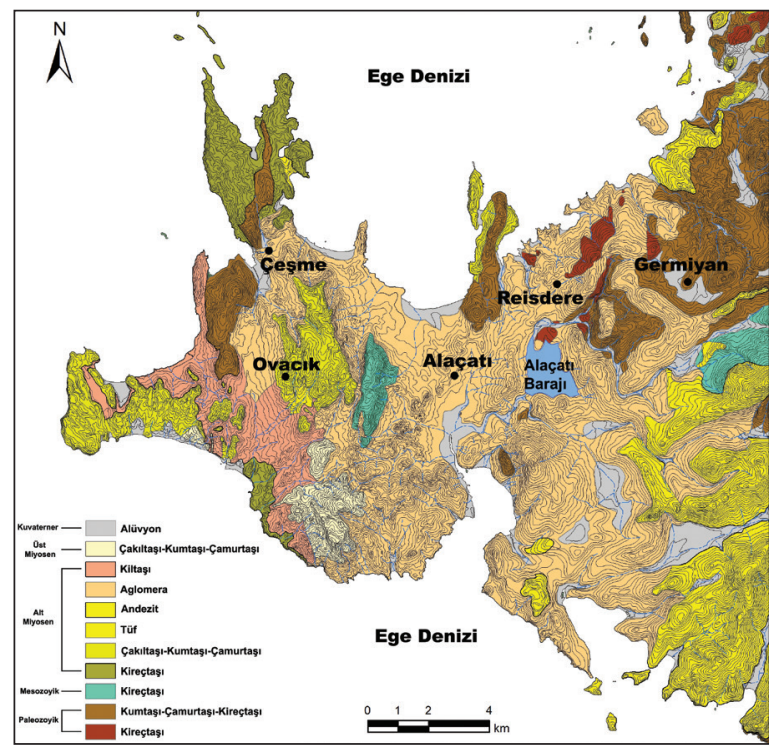

Şekil 2. Çeşme Yarımadası'nın Jeoloji Haritası (MTA 2017)

Figure 2.Geological Map of The Çeşme Peninsula (MTA 2017)

Kuvaterner'de ve özellikle Holosende kıyı bölgelerimizde hızlı jeomorfolojik değişmeler meydana gelmiştir (Kayan 1995, 1996, 1997, 1999; Öner 2016). Son buzul çağında -130 metrelerde olan Dünya denizlerinin seviyesi, Orta Holosen'e kadar bugünkü seviyesine yükselmiş ve özellikle akarsu ağızlarına karşılık gelen alçak kıyılarda iç kesimlere sokulup koy ve körfezler oluşturmuştur. Orta Holosen'de deniz seviyesi yükselmesinin durmasıyla bu kez koy ve körfezler alüvyonlarla dolarak kıyı çizgisi deniz yönünde ilerlemiştir (Kayan, 1988, 1996 ve 2012; Waelbroeck vd., 2002 ve Brückner vd., 2010). Bu dönemlerde kıyılarda liman kentleri olarak kurulan eski yerleşmeler, giderek kıyı çizgisinden oldukça içerilerde kalmış ve önemlerini kaybetmişlerdir (Kayan, 1995, 1997 ve 1999; Öner, 2013 ve 2016). Paleocoğrafya ve jeoarkeoloji araştırmalarımızla Çeşme civarında ortaya koyduğumuz tarihsel gelişim günümüzde bazı kesimleri alüvyonlarla örtülen bu tip antik yerleşmelerde süren arkeolojik kazı çalışmalarına katkılar sağlayacaktır.

Paleocoğrafya araştırmalarının arkeolojiye olan katkıları yanında, geçmiş dönemlerdeki coğrafi çevre değişmelerinden hareketle, gelecekte olabilecek bu tür değişmelerin olumlu ya da olumsuz etkilerini yorumlamak ve gerekli önlemleri alabilmek açısından da önemi fazladır. Liman Deresi depresyonunda ve Bağlararası'nda bulunan eski yerleşmelerin de ilk kuruldukları dönemden bugüne doğal/coğrafi çevreleri oldukça değişmiştir. $\mathrm{Bu}$ alanda kıyı çizgisinin en fazla nereye kadar sokulduğu, Bağlararası'na kadar ulaşıp ulaşmadığı bu alandaki önemli sorulardır. Alüvyal alanda yapılan delgi sondajlarla Bağlararası çevresinin paleocoğrafya özellikleri, kıyı çizgisi ve deniz seviyesi değişmeleri araştırılmış ve arkeolojik sorular yanıtlanmaya çalışılmıştır. Doğal çevre değişmelerinin izleri bu depresyonu kaplayan alüvyal-kolüvyal dolguların içinde kayıtlıdır.

\section{ÇEŞME BAĞLARARASI ARKEOLOJIK SİT ALANI VE LIMAN DERE VADİ TABANINDA GERÇEKLEŞTIRILEN DELGİ SONDAJ ÇALIŞMALARI}

Bağıl deniz seviyesi değişmeleri ile tarih öncesi çağlardan beri süren insan-çevre ilişkilerine 1 şı 
tutabilecek fiziki çevre değişmelerinin belirlenmesi için temel veri kaynaklarından birini farklı ortamlarda birikebilen çökeller oluşturmaktadır. Bir havzada biriken sedimanter katmanları ayrıntılı olarak incelemek için ise temel yöntemi delgi sondajları oluşturmaktadır. Delgi sondaj çalışmaları bu alanda 4600 yıl öncesine ulaşan ilk yerleşimlerden günümüze kadar geçen sürede meydana gelen çevresel değişimlerin belirlenmesi amacı ile yapılmıştır. 2016 yılının Eylül ayında sit alanı ve yakın çevresinde, derinlikleri 2 ila 9 metre arasında değişen toplam 10 adet alüvyal delgi sondaj yapılmıştır (Şekil 3). Bu sondajların amacı öncelikle kıyı çizgisi değişmelerini, ilk yerleşim yüzeyini ve o dönemden günümüze çevresel değişmeleri belirlemektir. Örneğin ÇB10 numaralı sondajın bulunduğu alanda Piri Reis haritalarında bir derenin varlığı araştırılmıştır (Şekil 4A). Yakın geçmişe ait haritalarda bile kıyı çizgisinin günümüzdekinden biraz farklı olduğu dikkati çekmektedir (Şekil 4B).

$\mathrm{Bu}$ gelişme aşamalarına zaman açısından bir yorum katabilmek için radyokarbon tarihleme analizleri yaptırılması gerekmektedir. Henüz tarihleme analizleri gerçekleşmemiştir. Gerçekleştirilen 10 adet sondajın arazideki gözlemleri, mikrofosil incelemelerine ve laboratuvar analiz sonuçlarına dayanılarak aşağıdaki değerlendirmeler yapılmıştır.

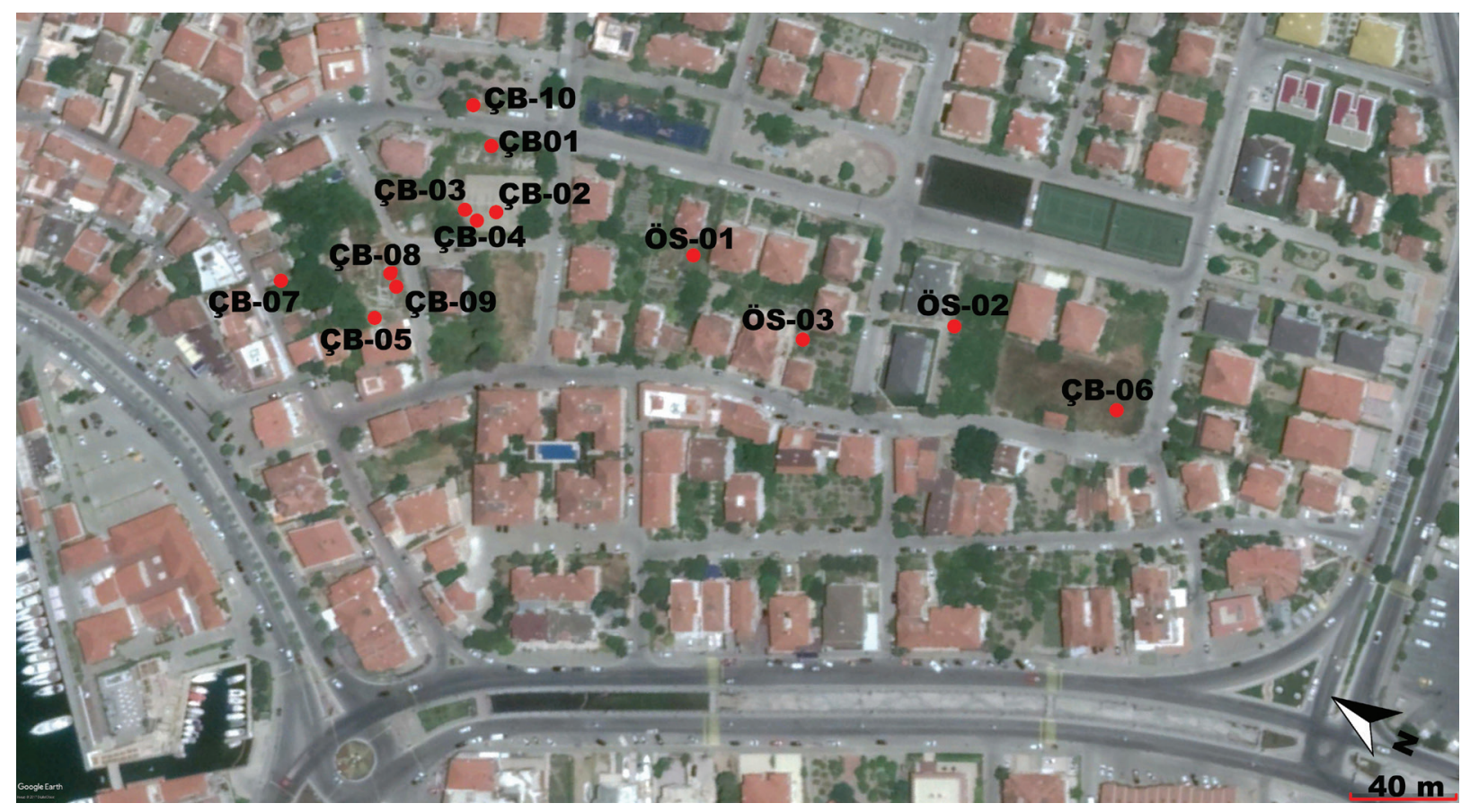

Şekil 3. Çeşme Limandere depresyonu ve Bağlararası kazı alanlarında delgi-özel sondajların konumları.

Figure 3. The Çeşme Limandere Depression and the locations of the Core-Private Drillings in Bağlararast, Excavations 


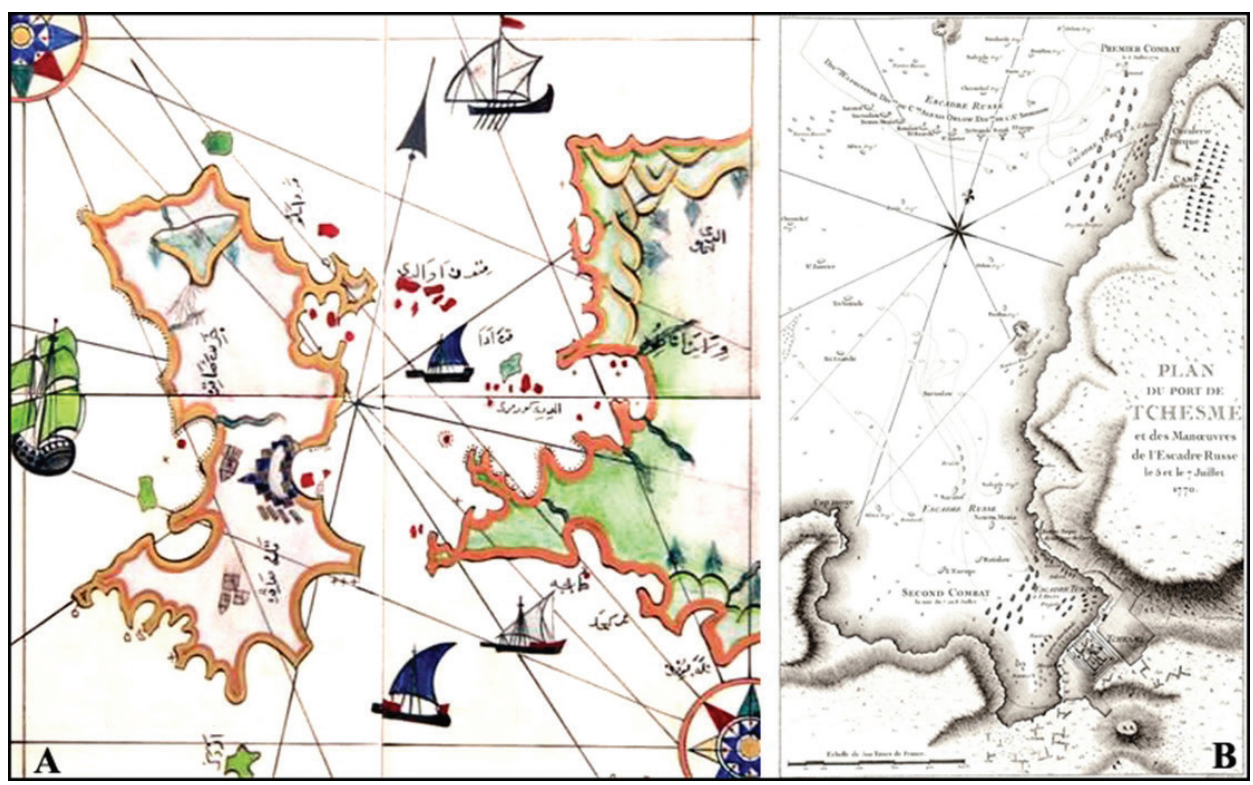

Şekil 4 A-B. Çeşme kıyıları; A-Piri Reis haritasında, B-1770'li yıllardaki bir haritada görünümü.

Figure 4. Çeşme shores; A-In The Piri Reis Map, B-Çeşme in The Map of 1770's

\section{Bağlararası ÇB-01 sondajı}

ÇB-01 sondajında arazide yapılan ilk gözlemlere göre yüzeyden itibaren $50 \mathrm{~cm}$ bölüm taşkın ovasıkolüvyal sedimanlardan oluşmakta olup daha aşağıya doğru arkeolojik dolgulara sedimanlara girilmektedir (Şekil 3 ve 5). Arkeolojik dolgunun içinde yüzeyden $155 \mathrm{~cm}$ aşağıda volkanik kül katmanına ulaşılmıştır. Hem sondajdan hem de yanındaki açmadan toplam 4 volkanik kül örneği alınmıştır. İnce ve kaba unsurların bir arada olduğu bu küllerin element analizleri yapılmıştır. $\mathrm{Bu}$ analizler özellikle "ince kül partiküllerinin" (Çeşme-1) günümüzden 3640 yıl önce Santorini adasındameydanagelmişolanMinoanpatlamasının külleri ile uyumlu olduğunu göstermiştir (Vardar ve Öner 2016a) (Çizelge 1). İnce küller içerdiği $\% 72,86$ oranındaki $\mathrm{SiO}_{2}$ ve 3,39 oranındaki $\mathrm{K}_{2} \mathrm{O}$ nedeniyle Minoan patlamasının element değerleri ile uyumlu görünmektedir. Bağlararası kazı katmanları içinde Erken Minos 1a tabakasının üzerine gelen küller Arkeolojik olarak da Mionan patlamasının meydana geldiği MÖ 1640'lı yıllara isabet etmektedir. Farklı sondajlarda esilen volkanik kül tabakası bunların deneştirilmesinde, başka değişle paleocoğrafyanın kurgulanmasında olanaklar sağlamaktadır (Vardar ve Öner 2016b). Bu konu ilerleyen çalışmalarımızda daha ayrıntılı bir şekilde değerlendirilecektir.

Sondajin $50 \mathrm{~cm}$ ile $4 \mathrm{~m}$ derinlikleri arasındaki arkeolojik dolgular geçilirken 500-560 cm arasında kavkılı denizel kumlara ulaşılmıştır. $\mathrm{Bu}$ birim denizel mikrofosiller içermektedir (Şekil 5). 560 cm'nin altında yeşilimsi renkli kil taşı ankayasına girilmiş ve $770 \mathrm{~cm}$ 'den itibaren karbonatl anakayaya geçilmiştir. ÇB-01 sondajının gerek arazi gerekse laboratuvar analizleri ile yapılan bütün incelemeler sonucu şu değerlendirmeler yapılabilmiştir; Sondajın yüzeyden itibaren ilk 440 cm'lik bölümü kolüvyal karasal dolgular ve bunlarla karışık insana ait kültür kalıntılarından oluşmuştur. 440 cm'den itibaren kıyı bataklığ 1 ile başlayan denizel ortama geçilmekte, $600 \mathrm{~cm}$ 'lerde de killi ana kayaya ulaşılmaktadır. $\mathrm{Bu}$ sondajın yüzey yükseltisi $170 \mathrm{~cm}$ olduğuna göre, bugünkü deniz seviyesinin $270 \mathrm{~cm}$ aşağısında denizel ortama geçildiği anlaşılmaktadır. $\mathrm{Bu}$ sondajda Minoan tüfüne kültür katmanı arasında yüzeyden 1,5 metre kadar aşağıda rastlanmıştır. Bu kül 
seviyesi arkeolojik kazı çukuru yamacında da gözlenmektedir.

\section{Bağlararası ÇB-02 sondajı}

ÇB-02 sondajnın derinliği $700 \mathrm{~cm}$ olup yaklaşık $150 \mathrm{~cm}$ aşağıda kazı çukuru içinde gerçekleşmiştir. Böylece yüzeyden $850 \mathrm{~cm}$ derine inilmiştir (Şekil 3 ve 6). Yüzeyden $160 \mathrm{~cm}$ derine kadar arkeolojik dolgu geçilmiştir. 160-300 cm aras1 bol bitki kalıntılı ve bol odun kömürü ve seramik parçaları içeren bir tabaka içinde geçilmiştir. 300420 arasında bol kavkılı çamur geçilmiştir. Bu birim denizel mikrofosiller içermektedir (Şekil 6). $420 \mathrm{~cm}$ 'nin altında anakayaya ulaşı1mıştır. $\mathrm{Bu}$ durumda yüzey kotuna ulaşmak için gereken $150 \mathrm{~cm}$ eklendiğinde yüzeyden $4 \mathrm{~m}$ aşağıya kadar arkeolojik dolgu, onun altında bitki katkı1ı ve kavkı1ı sığ denizi yansıtan katman geçilmiş ve 560-570 cm derinlikte anakayaya girilmiştir (Şekil 6). ÇB-02 sondaj1 yüzey yükseltisi 170 olan kenar kesimden $150 \mathrm{~cm}$ derinlikte açılmış kazı çukuru tabanında yapıldığı düşünüldüğünde, doğal yüzeyden $310 \mathrm{~cm}(150+160 \mathrm{~cm})$ derinliğe kadar kolüvyal karasal dolgular ve bunlarla karışık insana ait kültür kalıntılarından oluşmuştur. Yine kazı çukuru üstünde kalan doğal yüzey düşünüldüğünde, 310-390 cm'ler arasında kıyı bataklığ 1 ile birlikte fosilleriyle tanımlanan denizel ortama girilmekte ve $590 \mathrm{~cm}$ 'lere kadar bu sığ deniz ortamı devam etmektedir. $590 \mathrm{~cm}$ 'lerden itibaren killi; $750 \mathrm{~cm}$ 'lerde killi-siltli anakayaya geçilmektedir.

\section{Bağlararası ÇB-03 sondajı}

ÇB-03 sondajında yüzeyden $160 \mathrm{~cm}$ aşağıda kazı çukurunda yapılmış ve çukur tabanından 150 $\mathrm{cm}$ aşağıda duvar kalıntıları geçilememiştir (yüzeyden $310 \mathrm{~cm}$ aşağıda). Bu nedenle anlatımda şekil kullanılmamıştır. Bu sondajın tüm sediman örnekleri arkeolojik dolgu niteliğindedir. ÇB03 Numaralı sondajin yorumu bunun tamamen kolüvyal karasal dolgular ve bunlarla karışık insana ait kültür kalıntılarından oluşmuş bir ortamda oluştuğunu göstermektedir.

\section{Bağlararası ÇB-04 sondajı}

ÇB-04 sondajı Bağlararası kazısı içinde yükseltisi $170 \mathrm{~cm}$ olan doğal yüzeyden $170 \mathrm{~cm}$ aşağıdaki tabanda yapılmıştır (Şekil 3 ve 7). Sondajda 600 $\mathrm{cm}$ derine inildiğinden, yüzeye kadar olan 170 $\mathrm{cm}$ de dikkate alınırsa, toplan derinliğin 770 $\mathrm{cm}$ oluğu görülür. Yani karot taban1, bugünkü deniz seviyesinin 6 metre altında bulunur. $\mathrm{Bu}$ sondajda höyük çukuru tabanından itibaren 50$400 \mathrm{~cm}$ arası arkeolojik dolgu, 400-460 cm arasındaki katman sı̆̆ deniz içindeki höyük sedimanları, $460 \mathrm{~cm}$ den derinde ise anakaya bulunmaktadır. $\mathrm{Bu}$ değerlere $170 \mathrm{~cm}$ 'lik yüzey kotu fark1 eklendiğinde anakayaya $640 \mathrm{~cm}$ 'de girildiği görülmektedir. $\mathrm{Bu}$ durumda 2. Bin yerleşiminin 3. Bin yerleşimine komşu köşesinden denize doğru anakaya yüzeyinin eğimli olduğu ve ÇB-01 sondaj1 ile 1m'lik kot fark1 yaptığ düşünüldüğünde yaklaşık $3^{\circ}$ 'lik bir eğim olduğu anlaşılmaktadır. ÇB-04 numaralı sondajın gerek arazi gerekse laboratuvar analizleri ile yapilan bütün değerlendirmeler sonucu yorumlanmasıyla şu değerlendirmeler yapılabilmiştir; $\mathrm{Bu}$ sondaj $170 \mathrm{~cm}$ yükseltiye sahip doğal yüzeyden 170 $\mathrm{cm}$ aşağıdaki kazı çukuru tabanında yapılmıştır. $\mathrm{Bu}$ durumda bugünkü deniz seviyesi " $0 \mathrm{~m}$ " sondajın başlangıç düzeyini oluşturur. Sondajın ilk 1 metresi kolüvyal karasal dolgulardan oluşur. Yaklaşık 1 ila 2 metre seviyeleri arasında yapılara ait mermer ve taş parçaları kesilmiş durumdadır. Buna göre kazı çukuru üzerindeki doğal yüzey seviyesi olan $170 \mathrm{~cm}$ de eklendiğinde $370 \mathrm{~cm}$ 'lik kısmın karasal kolüvyalardan oluştuğu ve içinde kültürel kalıntılar bulunduğu söylenebilir. 200 cm'lerden 460 cm'lere kadar olan bölüm denizel sedimanlardan oluşmaktadır. $\mathrm{Bu}$ birim denizel mikrofosiller içermektedir (Şekil 7). Bu durumda bugünkü deniz seviyesinin 2 metre altında denizel sedimanlara girildiği ve yaklaşı $260 \mathrm{~cm}$ derinlikte sı ̆g denizel ortamın bulunduğu anlaşılır. Daha derinde ise killi anakayaya geçilir (Şekil 7). 

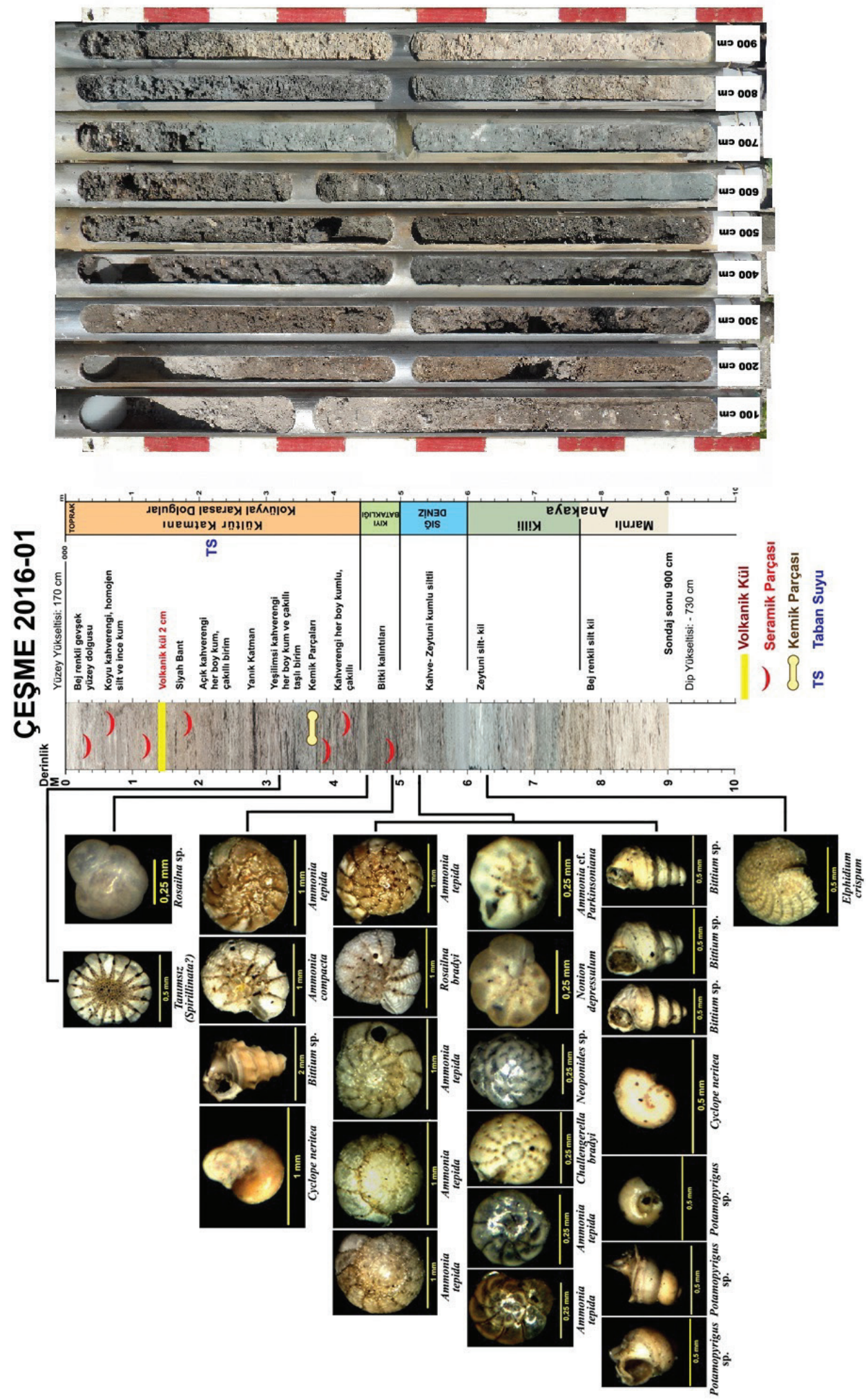

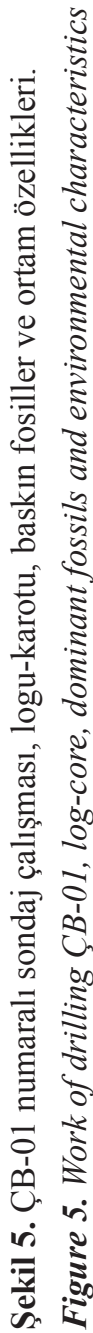



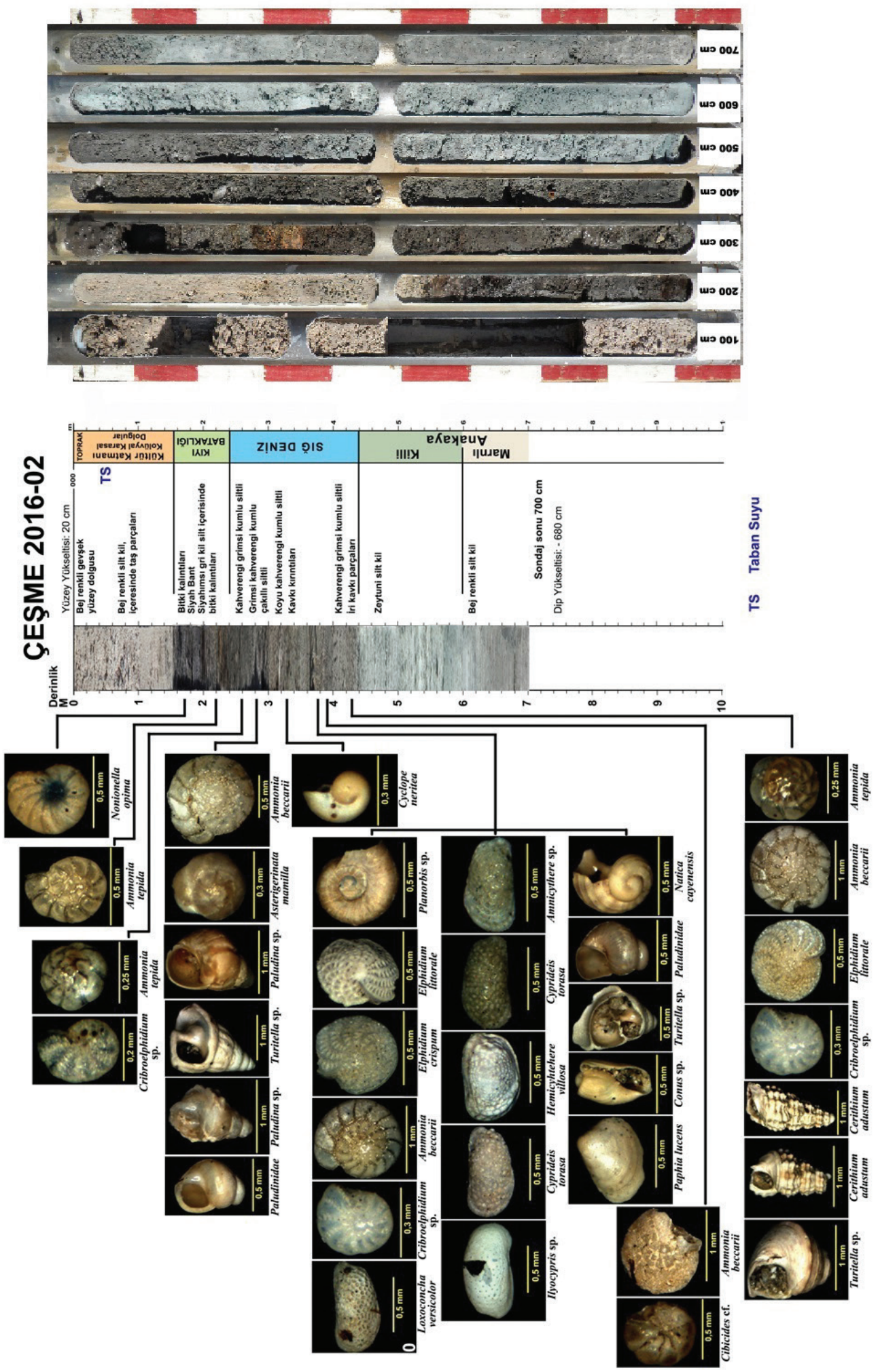

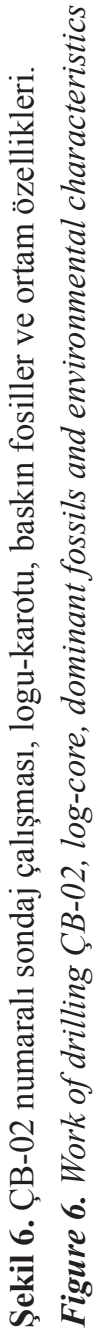



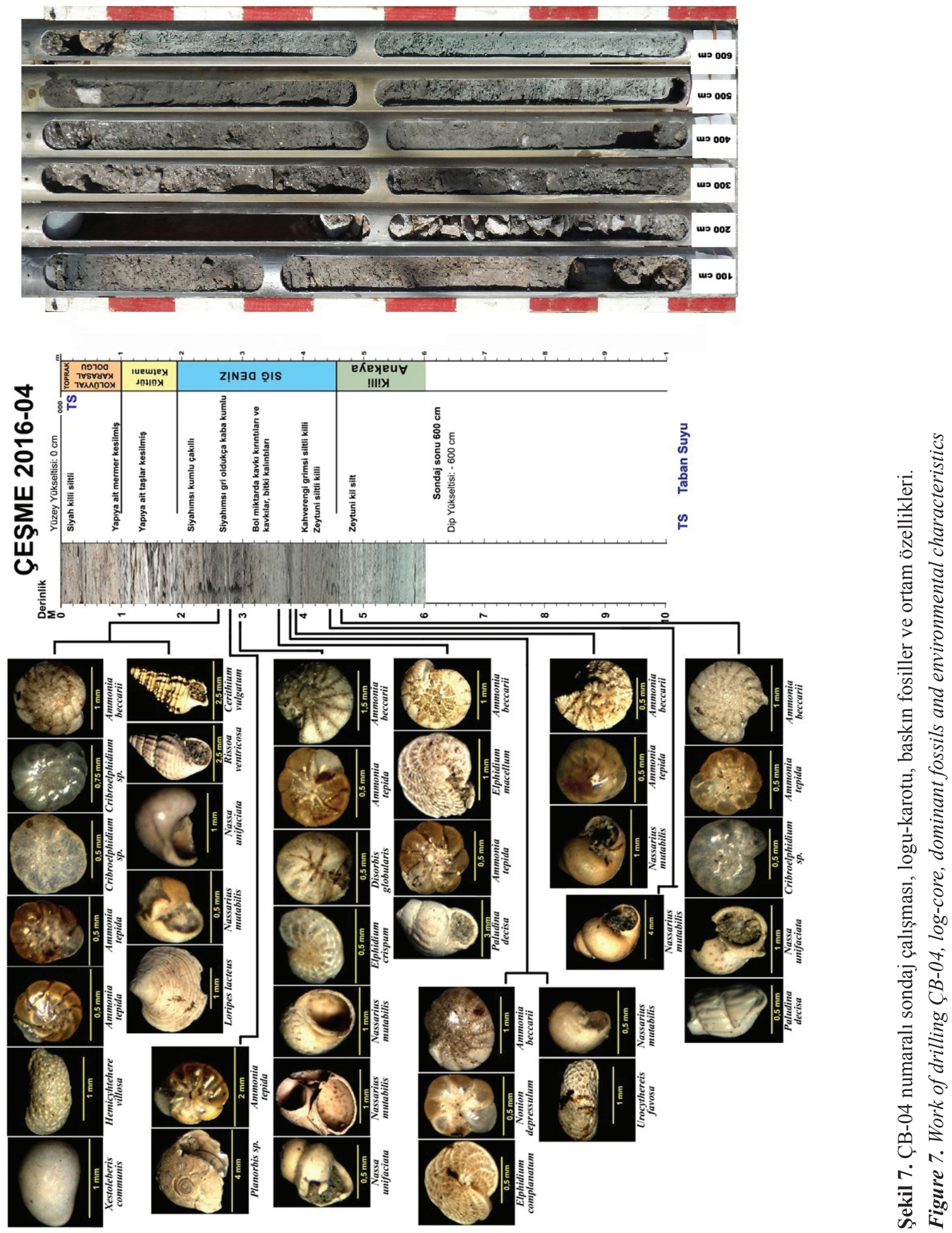


\section{Bağlararası ÇB-05 sondajı}

ÇB-05 sondajı Bağlararası kazı alanında MÖ 3. binyıl yerleşmesinin köşesinde yapılmıştır (Şekil 3 ve 8). Kazı alanının yanındaki doğal yüzeyin yükseltisi $188 \mathrm{~cm}$ olup sondaj bu seviyeden $145 \mathrm{~cm}$ aşağıdaki kazı çukuru tabanında başlamıştır. Buna göre sondaj noktası yükseltisi $43 \mathrm{~cm}$ ' dir. Sondajda yüzeyden $425 \mathrm{~cm}$ derine kadar arkeolojik bir dolgu geçilmiştir. 4. metreden sonra bol kumlu taş parçalı ve bitki artıkları ile büyük odun parçaları içeren kavkı1ı bir katman geçilmiş ve bu katmanın tabanında temiz kıyı kumu niteliğindeki bir tabaka (40 cm kalınlığında) geçilerek doğrudan anakayaya ulaşılmıştır. Bu durumda transgresyon yüzeyini temsil eden kumlu bir birim ve daha sonra Bronz Çăgı regresyonu ile birlikte yerleşimin başladığı ve kültür katının taban bölümünde bir kıyı bataklığının geliştiği anlaşılmaktadır. Eski höyügüun kazı tabanında yapılan ÇB-05 numaralı sondajın verileri ile değerlendirmeler yapılabilmiştir; Sondaj yüzeyinden $120 \mathrm{~cm}$ derinliğe kadar kolüvyal karasal dolgular, 120$325 \mathrm{~cm}$ 'ler arasında sediman ve içerdiği fosillerle tanımlanan (Şekil 8) kıyı bataklığı, 340 cm'lerden 575 cm'lere kadar tabanı kıyı bataklığı ile sona eren, sediman özellikleri ve fosilleri ile sı ̆ deniz ortamı geçilmiştir. Bu derinlikten itibaren de killi anakayaya girilmiştir. Sondaj $700 \mathrm{~cm}$ (doğal yüzeyden ise $845 \mathrm{~cm}$ ) derinlikte sona ermiştir. $\mathrm{Bu}$ noktada da 5 metreye yaklaşan derinlikte sı ̆ deniz ortamının bulunduğu anlaşılır (Şekil 8).

\section{Bağlararası ÇB-06 sondajı}

ÇB-06 sondajı kıyıdan en uzak sondaj olup Otobüs Terminal caddesinden bir önceki sokaktaki boş arsa kenarında yapılmıştır (Şekil 3 ve 9). Sondaj noktasının yüzey yükseltisi $310 \mathrm{~cm}$ olarak ölçülmüş olup $600 \mathrm{~cm}$ derine inilmiştir. Böylece sondajın tabanı bugünkü deniz seviyesinden $290 \mathrm{~cm}$ daha aşağıdadır (Şekil 9). Bu sondajda yüzeyden 4 metre derine kadar olan bölüm karasal kolüvyal bir dolguyu temsil etmekte, 4-5 metreler arası anakaya yüzeyini örten bozunmuş bir dolgu ve onun altında 5. metreden itibaren anakayaya girilmektedir. ÇB-06 sondajı Liman deresi depresyonunun kıyıdan $500 \mathrm{~m}$ içerisinde ve GD bölümünde yapılmıştır. Bu sondaj ve hemen yakınındaki özel sondajlardan ÖS-02 ve ÖS-03 denizin iç kesimlere hiçbir dönemde sokulmadığını göstermektedir. Özel sondaj ÖS01'de ise bir kıyı bataklığının uzantısı yakalanmış olabilir. Bu noktada gelecek çalışma döneminde bir seri sondaj yapılması önem kazanmıştır. Her üç özel sondaj ve ÇB-06 verilerine göre bu alanda akarsu sedimanı bulunmamaktadır. Daha çok yüzey selleri ile süpürülerek biriktirilen kolüvyal dolgular hâkimdir (Şekil 9). ÇB-06 Numaralı sondajın gerek arazi gerekse laboratuvar analizleri ile yapılan bütün değerlendirmeler sonucu yorumlanmasıyla tamamen kolüvyal karasal dolgular ve üstten 1 metresinde bunlarla karış1k insana ait kültür kalıntılarından oluşmuş bir ortam olduğu anlaşılmıştır. Sondajın 5. metresinde killi anakayaya ulaşılmış olup deniz ortamında birikmiş sedimana rastlanmamış ve alınan örneklerde fosil de bulunmamıştır (Şekil 9). 
늡 은

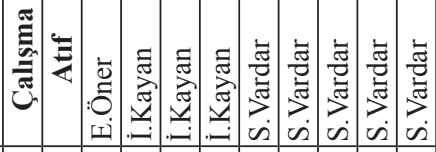

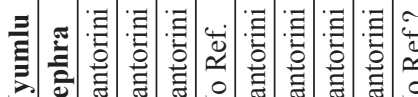

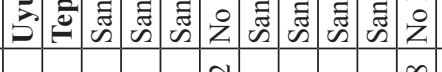

$\frac{2}{2}$

I

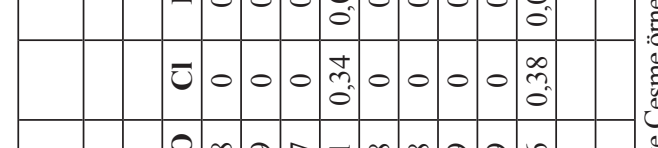

\section{竞 글}

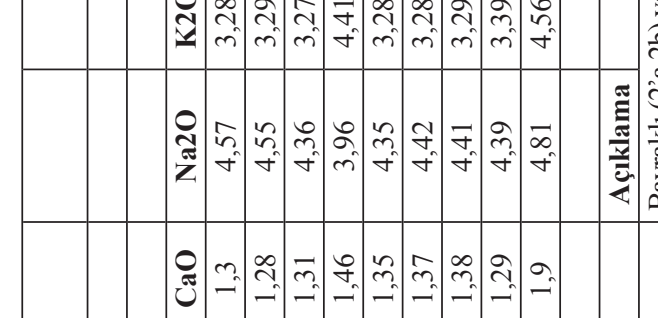
ลิ่ิ ज्ञ

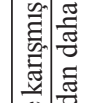

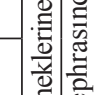

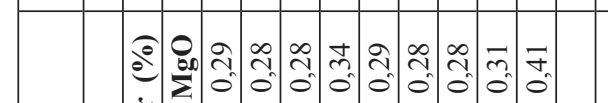

炡 产总

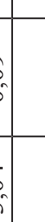

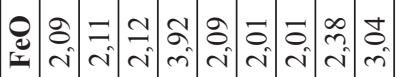

\begin{tabular}{|c|c|c|c|c|c|c|c|c|c|c|}
\hline & \begin{tabular}{l} 
రొ \\
\cline { 1 - 1 }
\end{tabular} & $\left|\begin{array}{l}+ \\
\infty \\
0 \\
0\end{array}\right|$ & $\begin{array}{c}\hat{\alpha} \\
\hat{\jmath}\end{array}$ & $\begin{array}{l}2 \\
\infty \\
-1\end{array} \mid$ & $\mid \begin{array}{c}1 \\
0 \\
0 \\
0\end{array}$ & $\mid \begin{array}{l}\hat{0} \\
\dot{I} \\
-\end{array}$ & $\begin{array}{l}\infty \\
0 \\
\pm \\
\pm\end{array}$ & $\begin{array}{l}0 \\
\vdots \\
\pm\end{array}$ & $\left|\begin{array}{c}n \\
0 \\
n\end{array}\right|$ & $\begin{array}{l}\infty \\
0 \\
-\end{array}$ \\
\hline 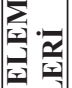 & ?ֶ. & $\begin{array}{c}\vec{n} \\
\hat{0}\end{array}$ & 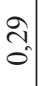 & $\begin{array}{c}\text { ते } \\
\text { ô }\end{array}$ & $\vec{F}_{0}$ & $\overrightarrow{\tilde{o}}$ & $\begin{array}{l}\hat{\imath} \\
\hat{0}\end{array}$ & $\begin{array}{l}\text { ते } \\
\text { ô }\end{array}$ & $\begin{array}{c}m \\
\hat{0} \\
0\end{array}$ & 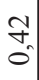 \\
\hline 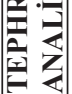 & ôn & $\begin{array}{l}2 \\
2 \\
\stackrel{f}{7}\end{array}$ & 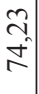 & $\begin{array}{l}\infty \\
\vdots \\
\mathbb{T} \\
\mathbb{\tau}\end{array} \mid$ & $\mid \begin{array}{l}8 \\
8 \\
0\end{array}$ & 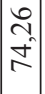 & $\begin{array}{l}\vec{v} \\
\dot{N}\end{array}$ & 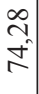 & $\left|\begin{array}{c}\infty \\
\infty \\
i \\
i\end{array}\right|$ & $\begin{array}{l}f_{n} \\
\hat{\sigma}\end{array}$ \\
\hline
\end{tabular}

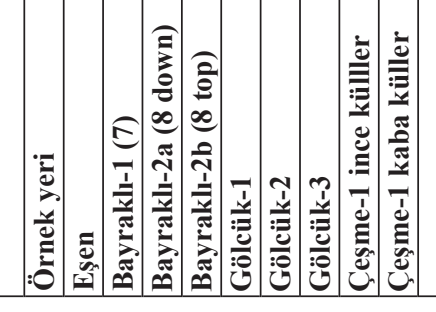

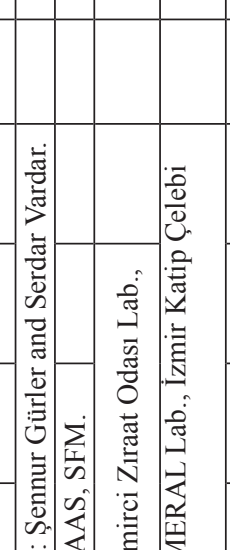

\begin{tabular}{|c|c|}
\hline Is & 0 \\
\hline $\bar{U}$ & 0 \\
\hline 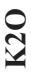 & $\stackrel{{ }_{n}}{\overbrace{0}}$ \\
\hline $\begin{array}{l}\text { O } \\
\mathcal{J} \\
Z \\
Z\end{array}$ & $\begin{array}{l}0 \\
\infty \\
+\end{array}$ \\
\hline $\begin{array}{l}0 \\
\text { లు }\end{array}$ & $\begin{array}{l}\infty \\
\stackrel{\sim}{=}\end{array}$ \\
\hline
\end{tabular}

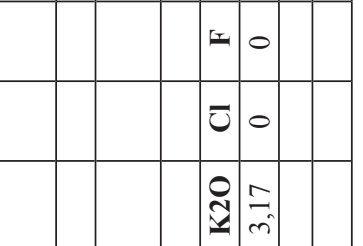

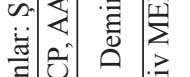

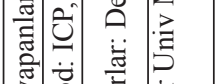
: 产

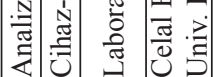
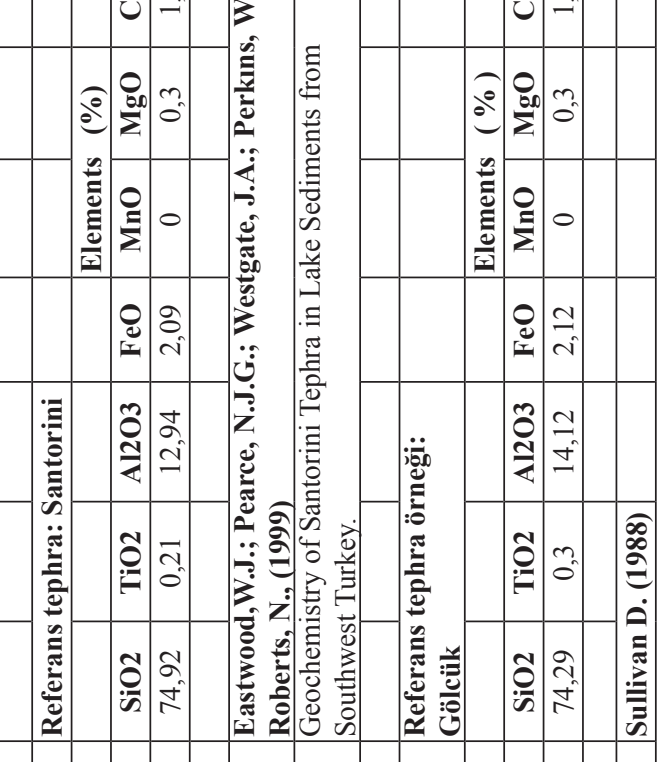

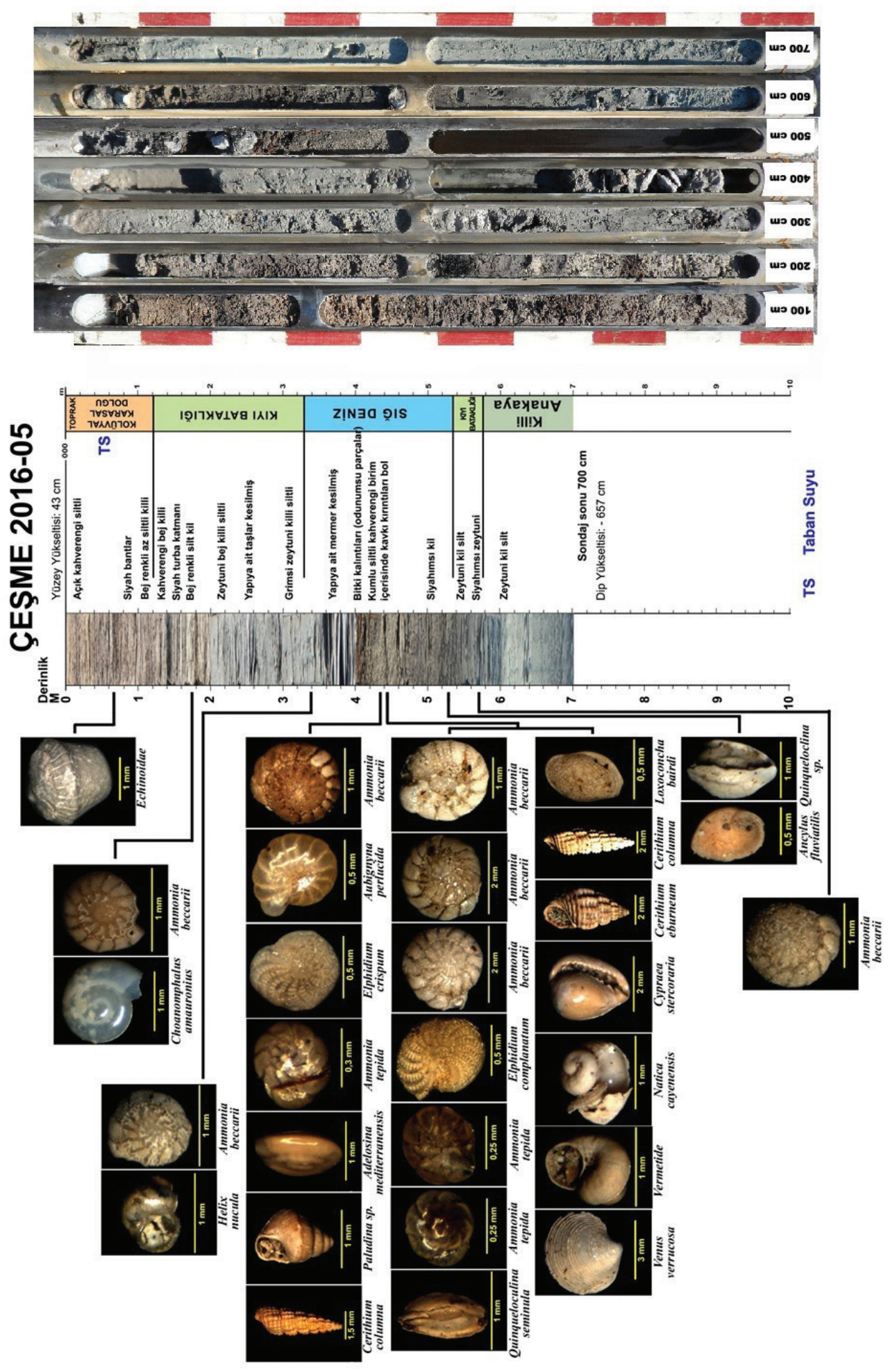

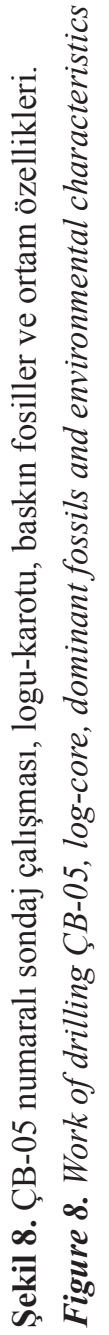




\section{Bağlararası ÇB-07 sondajı}

ÇB-07 sondajı Liman deresi depresyonunun KB kenarında kıyıya $20 \mathrm{~m}$ mesafede, Bağlararası çevresinde yapılan kıyıya en yakın sondajdır (Şekil 3 ve 10). Bağlararası ÇB-07 sondaj1 100 $\mathrm{cm}$ yükseltiden başlamış olup $800 \mathrm{~cm}$ derine inilmiştir. Buna göre bugünkü deniz seviyesinin $700 \mathrm{~cm}$ altına ulaşılmıştır (Şekil 10). Sondajın yüzeyden $625 \mathrm{~cm}$ derinliklerinde killi, 700 cm'lerinde ise marn anakayaya girilmiştir. Yüzeyden itibaren ilk 250 cm'lik bölümü karasal ortamı temsil eden alüvyal-kolüvyal dolgulardır. $250 \mathrm{~cm}$ 'den daha derine doğru sı̆ denizel koşulları gösteren fosil içermeyen, gleyi andıran mavimsi-grimsi renkli bir katman geçilmiştir. 500-580 cm'ler arası bol bitki artıkları, odunsu parçalar ve tabanında mermer parçaları bulunan az sayıda seramik (muhtemelen taşınmış) bulunan bir kıyı bataklığı geçilmiştir. 580-640 cm arasında fosilli (Şekil 10) iyi boylanmış kumlar geçilmiş ve daha sonra anakayaya girilmiştir. ÇB-07 de yerleşimin bulunduğu döneme ait katmandan yıkanan malzeme su ortamına taşınabildiği için kıyı bataklığı içinde seramiklerin bulunması olağandır. Kıyıya bu kadar yakın olunmasına rağmen sı̆̆ denize ait ince tabakaların dışında denizel tabakaların bulunmaması Limandere depresyonunun KB kenarındaki kıyı bölümünün geçmişte de sığ bir denizel ortam olduğu anlaşılmaktadır. ÇB-01 sondajında bulunan volkanik kül tabakasına da bu sondajda kıyı bataklığı tabanında rastlanmıştır (Şekil 10).

\section{Bağlararası ÇB-08 sondajı}

Sondaj ÇB-09 ÇB-08'in tekrarı olduğu için ÇB08'in anlatımında şekil kullanılmamıştır. ÇB-08 sondaj1 ÇB-04 ile ÇB-06 noktaları arasındaki kesiti tamamlamak amacıyla yapılmıştır. Ayrıca her iki yerleşim arasındaki en yakın nokta olması bakımından tercih edilmiştir. Taban suyu oldukça yüksek olduğu için örnekler tam anlamıyla iyi alınmamıştır. $\mathrm{Bu}$ nedenle bu sondajın yaklaşık 5 metre yakınında ÇB-09 noktasında yeni bir sondaj yapma gereği duyulmuştur. Bağlararası ÇB-08 sondajı MÖ 3. binyıl höyüğü kazı alanı içinde yapılmıştır. Sondaj kazı çukurluğunun kenarındaki doğal yüzeyden $210 \mathrm{~cm}$ aşağıda tabanda yapılmış olup, kazı öncesi yüzey yükseltisi $188 \mathrm{~cm}$ ölçüldüğü için, bu sondajın başlangıç noktası bugünkü deniz seviyesinden -22 cm daha aşağıda bulunmaktadır. ÇB-08 sondajında çukur tabanından $600 \mathrm{~cm}$ derine kadar ulaşılmıştır (Şekil 11). Bağlararası ÇB-08 sondaj1 kazı çukuru tabanında yüzeyden $22 \mathrm{~cm}$ derinde yapılmıştır. Sondaj $600 \mathrm{~cm}$ derine indiği için deniz seviyesinden $622 \mathrm{~cm}$ aşağı ulaşmıştır. Sondajın üst 200 cm'lik bölümü kolüvyal karakterli karasal dolgudan oluşmaktadır. $200 \mathrm{~cm}$ ile $500 \mathrm{~cm}$ 'ler arasında sediman ve fosilleri ile tanımlanan üstte turba karakterli kıyı bataklığı ile başlayan denizel ortama ait sedimanlar bulunmaktadır. Sondajın $500 \mathrm{~cm}$ 'den itibaren de killi anakayaya geçilmekte ve $600 \mathrm{~cm}$ 'de sondaj sona ermektedir. Buna göre ÇB-08 sondaj noktasının bulunduğu alanda Holosen transgresyonu ile denizin killi ana kaya üzerine ilerlediği ve yaklaşı 3 metre derinlikte sığ deniz ortamının bulunduğu ve bu alanın kolüvyal dolgularla karalaşması ile çevrede yerleşimlerin başladığı anlaşılmaktadır (Şekil 11). Bu noktada bugünkü deniz seviyesinin $200 \mathrm{~cm}$ altında karasal birime geçilmesi, Bronz Çağı regresyonu ile deniz seviyesinin alçaldığı dönem akla gelmektedir. $\mathrm{Bu}$ konuda turba karakterli kıyı bataklığ 1 biriminden alınan örneklerin tarihlenmesinden sonra daha kesin sonuca ulaşmak mümkün olabilecektir. Sondajın 200-260 cm'leri arasında turbamsı kıyı bataklığ1 içindeki yapı kalıntıları, seramik ve kemik parçalarının bulunması kıyı çizgisinin bu kesimde olduğu zamanda insanların buraya yakın kesimde yerleştiğini göstermektedir. 


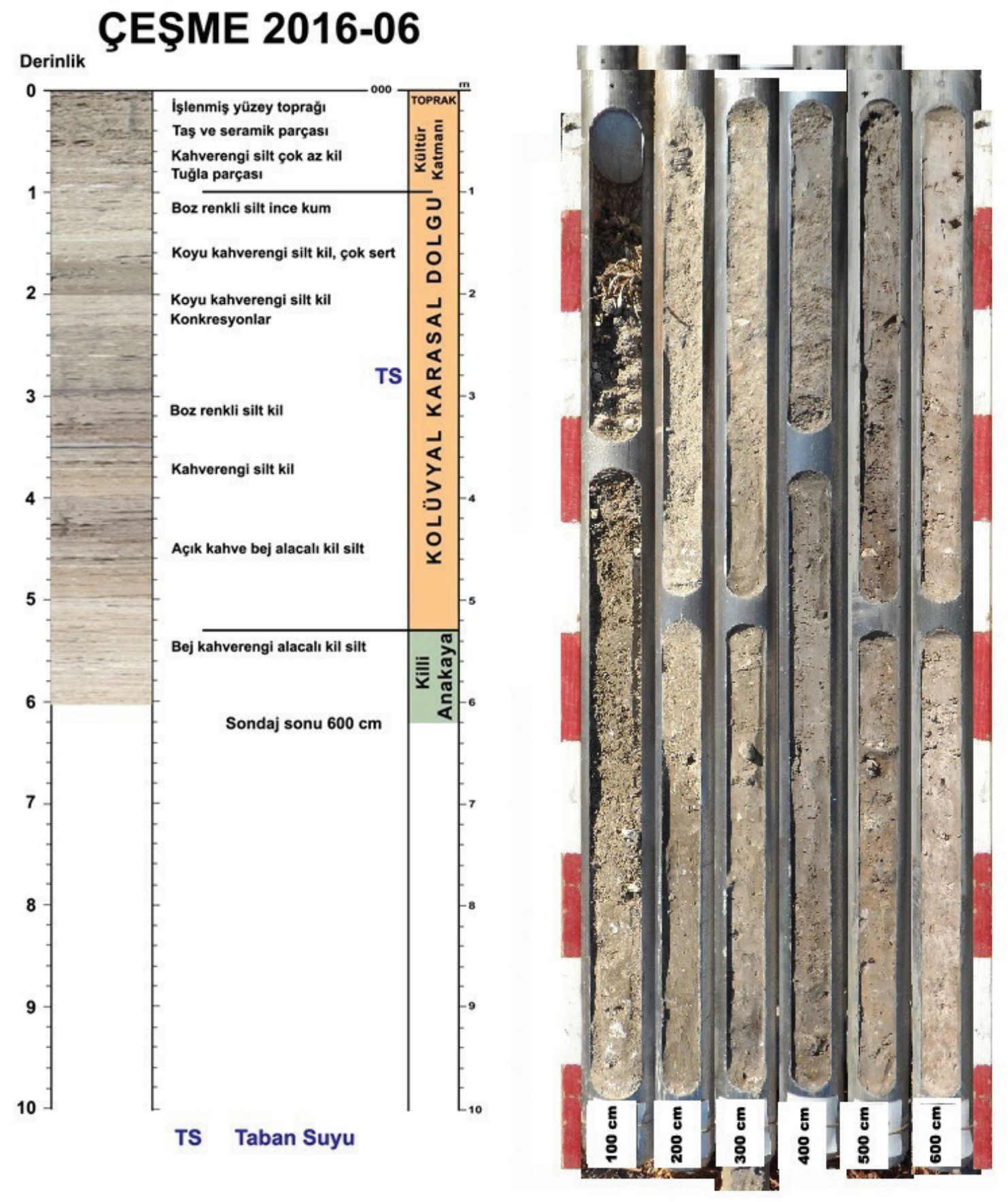

Şekil 9. ÇB-06 numaralı sondaj çalışması, logu-karotu ve ortam özellikleri.

Figure 9. Work of drilling ÇB-06, log-core and environmental characteristics 

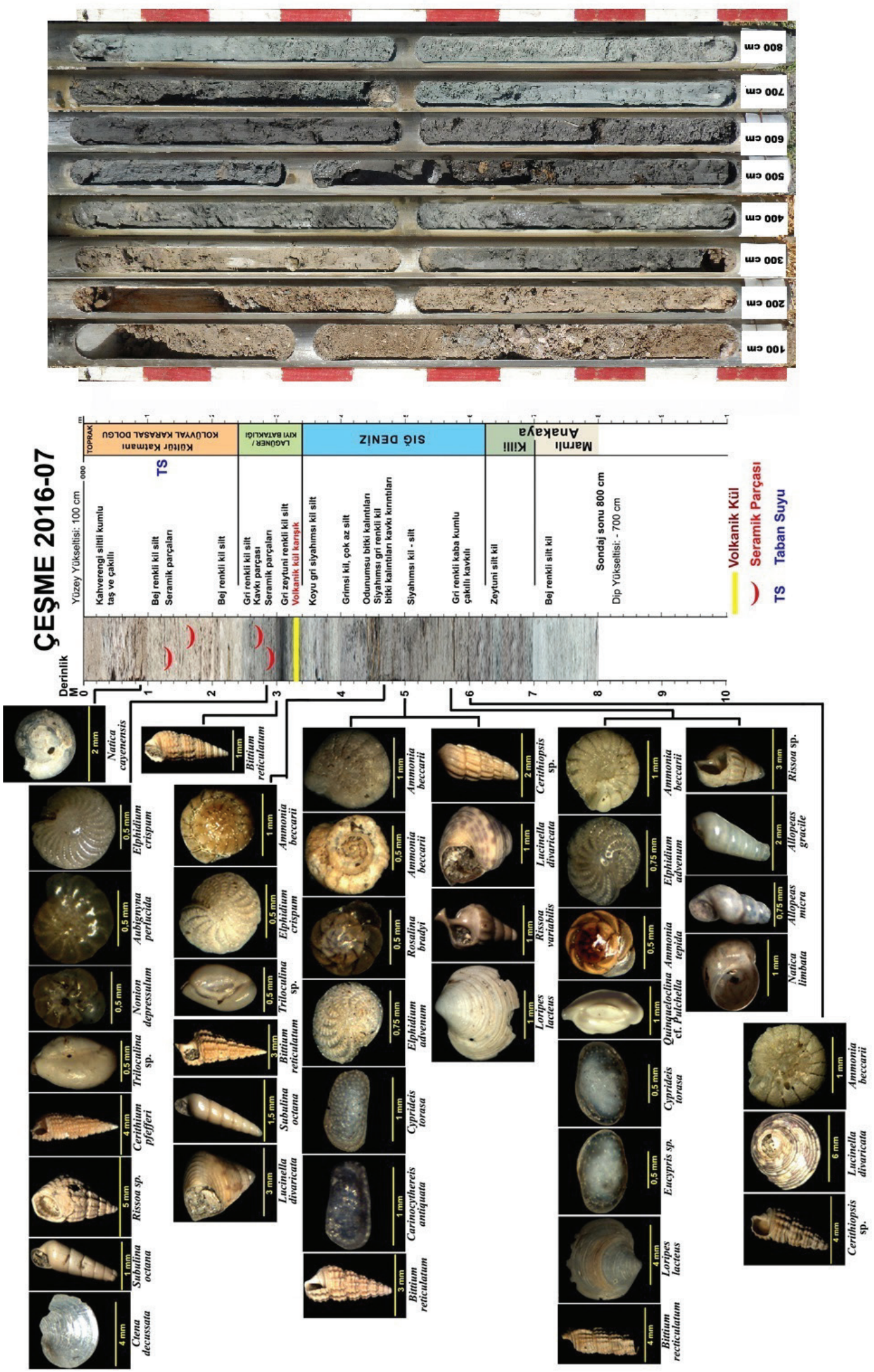

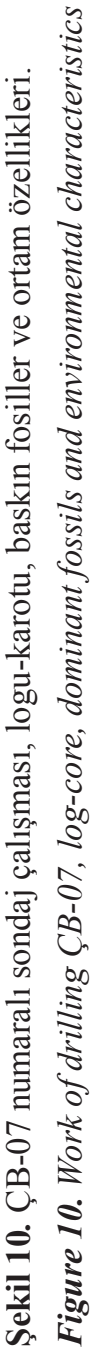



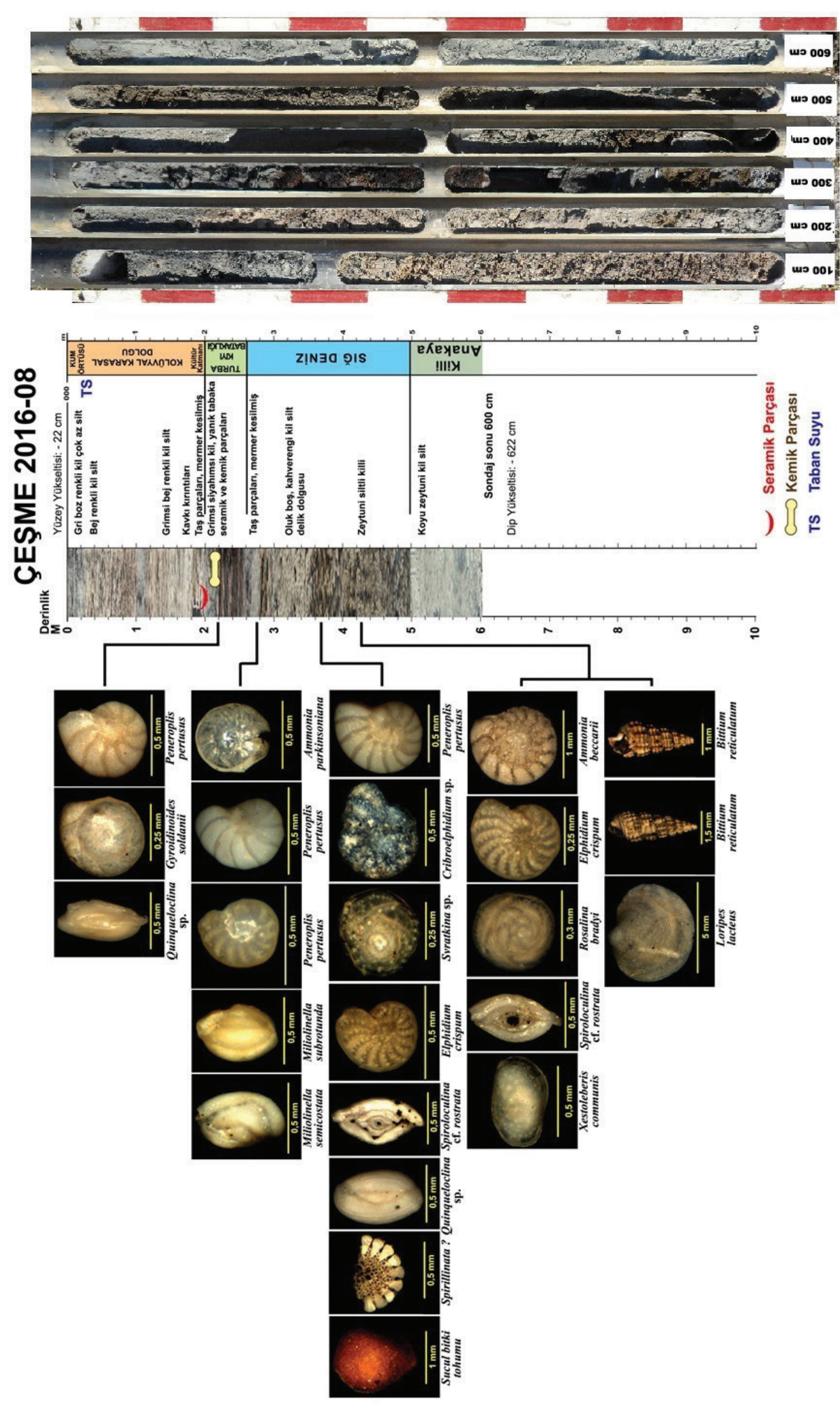

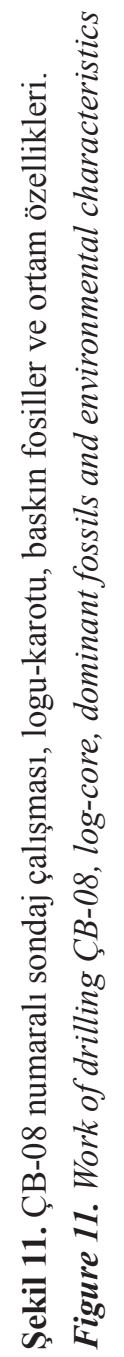




\section{Çeşme Bağlararası ÇB-09 sondajı}

MÖ 3. binyıl yerleşmesi kazı çukuru tabanındaki ÇB-08 sondajının 5 metre yanında yapılmıştır (Şekil 3). İlk iki metre arkeolojik dolgulardan oluşmaktadır. Bunun altında 200-360 cm arasındaki katman bol bitki kalıntıları, odunsu parçalar ve bol taş (mermer) parçaları ile az seramik kırıntısı içeren bir birime ulaşılmıştır. 370-450 cm'ler arası bol kumlu (çoğu yıkanmış temiz ve iri) dolguya ulaşılmıştır. Daha aşağıda 450 cm'den itibaren anakayaya girilmiştir. $\mathrm{Bu}$ stratigrafik durum Bağlararası MÖ 2. ve MÖ 3. biny1l yerleşimlerinin bulunduğu alandaki sondajlarda genel bir istifin yakalanmasını sağlamıştır. En altta anakaya (500 $\mathrm{cm}$ 'lerde) onun üzerinde $50 \mathrm{~cm}$ ortalama kalınlıkta bol kavkılı denizel kumlar, onun üzerinde bol taş parçalı ve bitkili, odunsu parçalar içeren turba görünümlü bataklık birimi, yüzeye kadar olan son 2-3 metrede ise arkeolojik dolgular dikkati çekmektedir.

ÇB-09 sondaj1 da ÇB-08 sondajına benzer ortam özelliklerine sahiptir (Şekil 11). Yüzeyden ilk $200 \mathrm{~cm}$ 'lik bölüm kolüvyal karasal dolgulardan, 200-450 cm'ler aras1 ise yine üstte kıyı bataklığı ile başlayan sığ deniz ortamından oluşmakta olup $450 \mathrm{~cm}$ derinde de killi anakayaya girilmektedir. ÇB-09 noktasında da killi anakaya üzerine transgresyonla gelen $250 \mathrm{~cm}$ derinlikte sığ bir deniz ortamının bulunduğu ve bugünkü deniz seviyesinin $220 \mathrm{~cm}$ kadar altında denizel ortamdan kıyı bataklığı ile karasal dolgulara geçildiği bunun da Bronz çağı regresyonu ile uyumlu olduğu anlaşılır.

\section{Bağlararası ÇB-10 sondajı}

MÖ 2. binyıl yerleşmesi kazı alanı giriş kapısı karşısındaki park içinde yapılmıştır (Şekil 3 ve 12). ÇB-10 sondajı Bağlararası yerleşiminden kuzeyindeki yamaca doğru anakayanın gidişini ve yamaç bölümündeki dolguları belirlemek için yapılmıştır. Ayrıca bu kesimde silik etek rölyefinin güney kenarı boyunca Piri Reis haritalarında görülen bir derenin var olup olmadığg sorgulanmıştır (Şekil 4A). Bu sondajın yüzey kotu 190 cm'dir. Yüzeyden $200 \mathrm{~cm}$ derine kadar kolüvyal dolgu ile karışmış halde bulunan höyük süprüntüsü arkeolojik dolgular geçilmiştir (Şekil 12). Sondajın 200-290 cm arası kıyı bataklı̆̆ 1,290 $540 \mathrm{~cm}$ arasında siyahımsı killi-kumlu, kavkı11mikrofosilli denizel sedimanları geçilmiştir (Şekil 12). $540 \mathrm{~cm}$ 'de anakayaya girilmek sureti ile sondaj $600 \mathrm{~cm}$ derinliğe ulaşılarak tamamlanmıştır. ÇB-01 sondajında $570-580 \mathrm{~cm}$ de girilen anakaya yüzeyi yaklaşık $30 \mathrm{~cm}$ 'lik bir yükselme ile ÇB-10 sondajına doğru uzanmaktadır. Her iki sondajda da anakaya yüzeyi yıkanmış bol kavkılı kumlar ile örtülmüştür. Bu durum tüm sondajlarda genel olarak gözlemlenen transgresyonun direk anakaya üzerine geldiği görüşünü doğrulamıştır.

\section{ÇEŞME BAĞLARARASI SONDAJ VERILERININN YORUMLANMASI}

Çeşme Bağlararası kazı alanı çevresinde ve Liman deresi depresyonunda yapilan sondajlarda depresyon tabanındaki Miyosen anakaya üzerinde Holosen transgresyonundan günümüze biriken alüvyal dolgularda 4 ana birim ayrılmıştır. $\mathrm{Bu}$ birimler anakayanın üzerinde yaşlıdan gence doğru; denizel çökeller (Erken Holosen transgresyonu), Kıyı Bataklığı çökelleri (Orta Holosen), kıyı düzlüğü karasal dolgusu (Orta-Geç Holosen) ve Bağlararası höyük dolgularıdır (OrtaGeç Holosen) (Şekil 13).

\section{Holosen Transgresyonu ve Denizel Ortam (Erken Holosen)}

Batı Anadolu'da Troia ve Bayraklı gibi alanlarda ulaşılan sonuçlar deniz seviyesinin Bronz Çağı'nda -2 m ye kadar düştügünü göstermektedir. Son buzul maksimumunda başlayan br transgresyonla günümüzden yaklaşık 7000 yıl önce deniz seviyesi günümüzdeki deniz seviyesine ulaşmıştır (Kayan 1988). Günümüzden 6000-5000 y1l önce deniz 
seviyesi kabaca bugünkü seviyesinde iken GÖ 5000-3000 yılları arasında -2 m civarında kalmıştır. Daha sonra günümüze doğru deniz seviyesi sürekli yükselmiş ve günümüzdeki seviyesine ulaşmıştır (Kayan 1988). Bağlararası mevkiinde Holosen transgresyonu ile yükselen deniz seviyesine bağlı olarak Limandere depresyonu tabanında bulunan Miyosen anakayanın üzerine doğrudan denizel çamurlar gelmektedir (Şekil 13). Zamanla anakayayı kaplayan deniz sı̆̆ ve zengin bir faunaya sahiptir. $\mathrm{Bu}$ ortama ait ilk değerlendirmeler denizel ortamı temsil eden foraminiferlerin bol miktarda bulunduğunu göstermiştir. Bu konuda detaylı çalışmalarımız devam etmektedir. Bol kavkı ve Bittium içeren koyu gri renkli denizel çamurlar Limandere depresyonunun ve Bağlararası mevkiinin en yaşı birimi denizel çökellerdir (Şekil 13).

Bağlararası mevkiinde Limandere depresyonu tabanındaki anakaya yüzeyinde denizel birimi anakayadan ayıran çok ince bir katman bulunmaktadır. Bu katman denizel birimin içinde olup en altındadır. Açık gri renkli katman Holosen transgresyonu yüzeyini temsil etmektedir. $\mathrm{Bu}$ yüzey dikkate alındığında günümüzden 70006000 yıl önce kıyı günümüzdeki kıyıdan yaklaşık $280 \mathrm{~m}$ içeriye kadar sokulmuştur (Şekil 14A, $15 \mathrm{~A})$.

\section{Kıyı Bataklığı (Orta Holosen)}

Bağlararası Limandere depresyonunun denizel biriminin üzerinde kıyı bataklığı sedimanlarının oluşturduğu 1-3 m kalınlığındaki bir katman yer almaktadır. Holosen transgresyonu sonrası hizla yükselen deniz seviyesinin GÖ 5000 yılından itibaren alçalmaya başlaması ve $-2 \mathrm{~m}$ kadar gerilemesi daha önce sığ bir denizle kaplı olan alanda kıyı bataklığı koşullarının ortaya çıkmasını sağlamıştır (Şekil 13). Kıyı bölümünde bugünkü Bronz Çağ kazı alanlarının bulunduğu alan bir kıyı bataklığı halini almıştır. Kıyı bataklığında kıyı bataklığı bitkilerine ait gövde ve diğer parçalar ile odunsu bitki unsurları bulunmaktadır.
$\mathrm{Bu}$ bataklık katmanının üst bölümlerinde karasal koşulların ortaya çıkmasıyla yerleşime uygun bir zemin ortaya çıkmıştır. Yerleşime ait kültür katmanının çok ince bir bataklık katmanı üzerinde GÖ 5000 yılından itibaren Bronz Çağ1 regresyonu ile başlaması giderek karalaşan alanda gelişmesi ve GÖ 4000 yerleşiminin de bu alanda devamlılık gösterecek şekilde var olması, Bağlararası kıyısında yerleşimin Bronz Çă̆ regresyonu ile uyumlu olarak ortaya başladığını göstermektedir (Şekil 13). Bronz Çağ1 regresyonuna ait yerleşimle bağlantılı izlerin Bayraklı ve Troia'da da bulunduğu bilinmektedir (Kayan 1988). Kıyı bataklığında kıyı bataklığ bitkilerine ait gövde ve diğer parçalar ile odunsu bitki unsurları bulunmaktadır. $\mathrm{Bu}$ bitkilerden yapılan botanik çalışması halen sürmektedir.

\section{Bağlararası Höyük Dolguları ve Tephra Katmanı (Orta-Geç Holosen)}

Bağlararası höyük dolguları yukarıda ifade edildiği gibi bataklık katmanının üzerine gelmektedir. Höyük dolgularının kalınlığı 4 m ye kadar ulaşmaktadır. Denize daha yakın olan MÖ 3. Bin yerleşimi (GÖ 5000) ile daha iç kesimde kalan MÖ 2. Bin yerleşimi (GÖ 4000) Tunç Çağ1 buluntu alanlarıdır (Şekil 13). Tarihi günümüzden 46000 y1l öncesine kadar götürülen bu alandaki kültür dolgularının tabanı bataklık katmanının üst kısmı ile karışmış olarak bulunmaktadır. Kültür katmanının tabanı dışındaki kesimlerinde yap1 izleri, duvarlar ve diğer belirgin arkeolojik öğeler yer almaktadır. Koyu kahve renkli yerleşim katmanı yanmış materyallere ait izler ve odun kömürü içermektedir. Kültür katmanı içindeki yapisal unsurlardan kuzey kenardaki duvarın hemen kenarında bugünkü yüzeyden $155 \mathrm{~cm}$ kadar aşağıda Tephra katmanı bulunmuştur. 2-3 cm kalınlığındaki bu katmanın element analizleri Santorini adasındaki Minoan patlaması ile uyumludur (Şekil 13). 

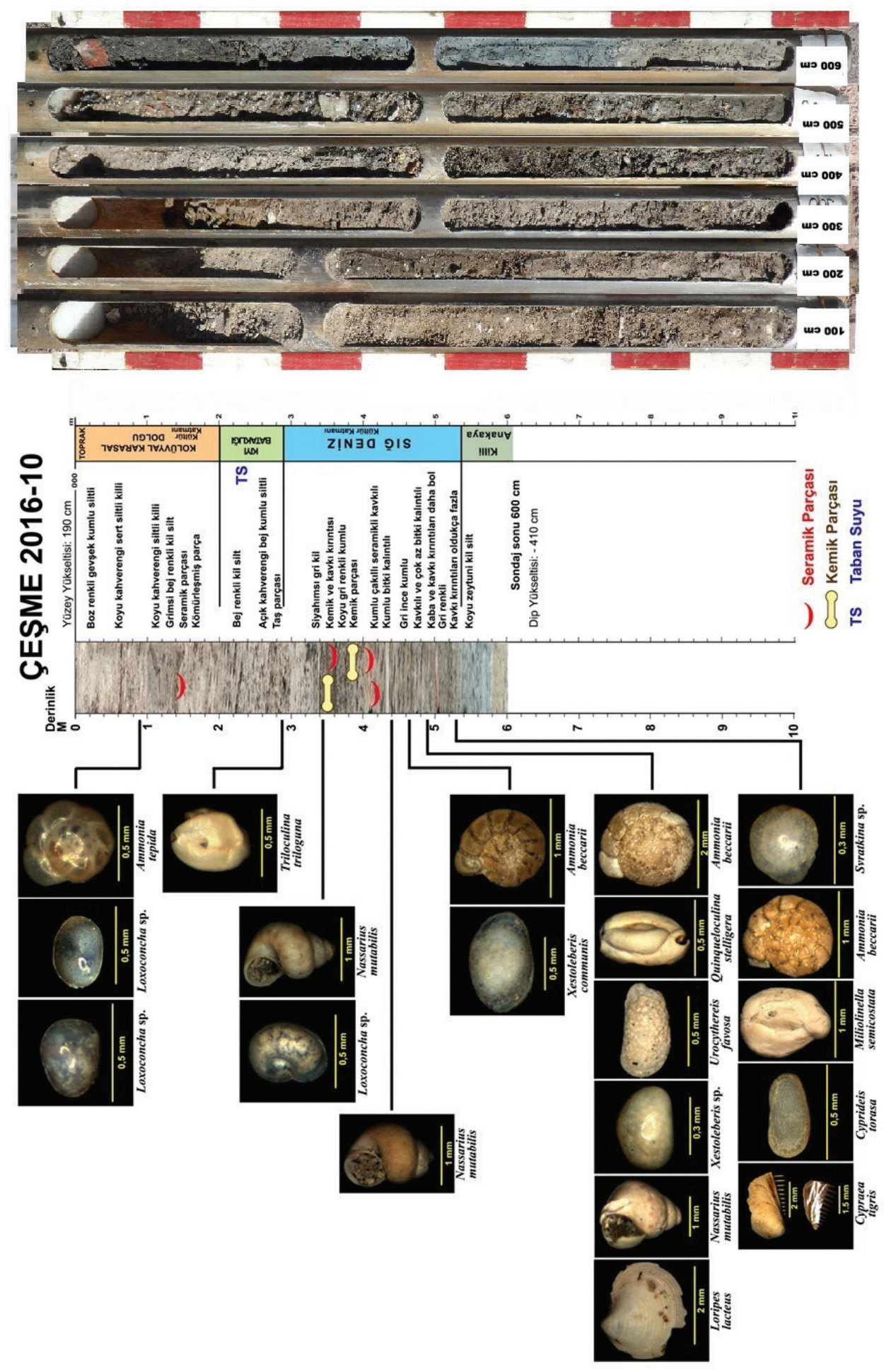

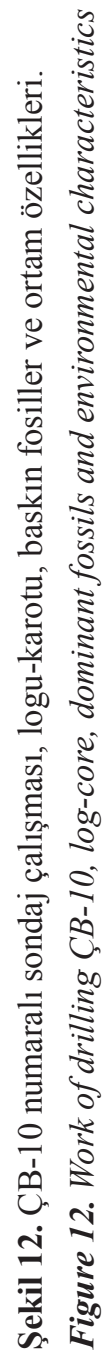




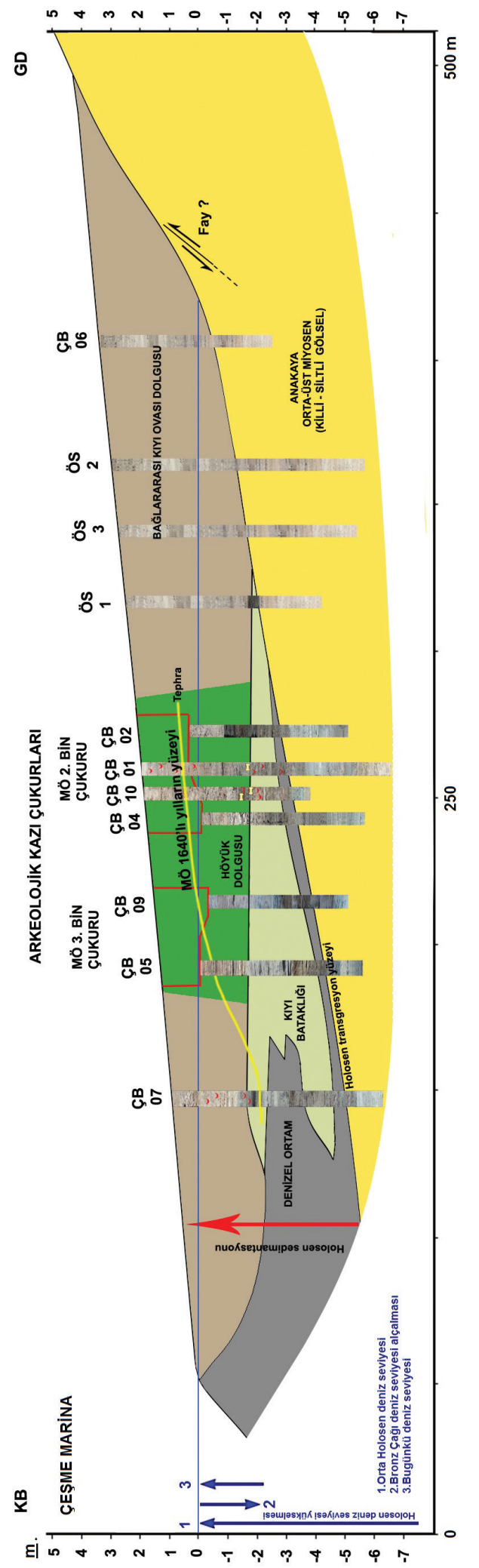

\section{Bağlararası kıyı düzlüğü örtüsü (Orta-Geç Holosen)}

Bağlararası çevresinde Kültür katmanları ve çevresi alüvyal-kolüvyal sedimanlarla örtülmüştür. Kalınlığ 2 ile $6 \mathrm{~m}$ arasında değişen bu katman güney kesimlerde Liman deresi yatağı çevresinde daha çok alüvyal bir materyali andırmaktadır. $\mathrm{Bu}$ bölümdeki sedimanlar yuvarlak kum taneleri ve küçük çakillar içermektedir. Ancak güneydeki bu dar kesim hariç daha çok yüzey selleri ile taşınarak birikmiş kolüvyal bir birim karakterindedir. Limandere depresyonu genelinde bol killi sert ve bol köşeli çakıl ve kaba kum içeren kolüvyal dolgular Bağlararası höyük materyalini de 50 cm-1 m arasında örtmüştür.

\section{PALEOCOĞRAFİK-JEOARKEOLOJIIK SONUÇLAR VE ÖNERILER}

Bağlararası çevresinde Holosen'de çevrenin nasıl değiştiği, yerleşimin bu değişimin içinde nasıl başladığ 1 ve çevre ile etkileşiminin nasıl geliştiği bu çalışmada yanıtı aranan sorular olmuştur. Bunun yanında Holosen dolgularının kronostratigrafik bir istif düzeni içinde değerlendirilmesi yapılmıştır. Holosen dolguları dört ana birimde ele alınmıştır. Bağlararası mevkii ve Liman deresi depresyonu güney kesiminde daha çok alüvyal malzeme birikirken genelinde yamaçlardan gelen sellerin taşıdığı kolüvyal malzeme depolanmıştır. Depresyonun KB kenarında Holosen transgresyonu ile deniz kara içine 280 m kadar sokulmuş ve GÖ 7000 kıyısı şekillenmiştir. Holosen transgresyonu doğrudan anakaya üzerine gelmiştir. Günümüzden 5000 yıl önceden itibaren deniz seviyesinde göreceli bir alçalma olmuş ve seviye $-2 \mathrm{~m}$ ye kadar düşmüştür. 

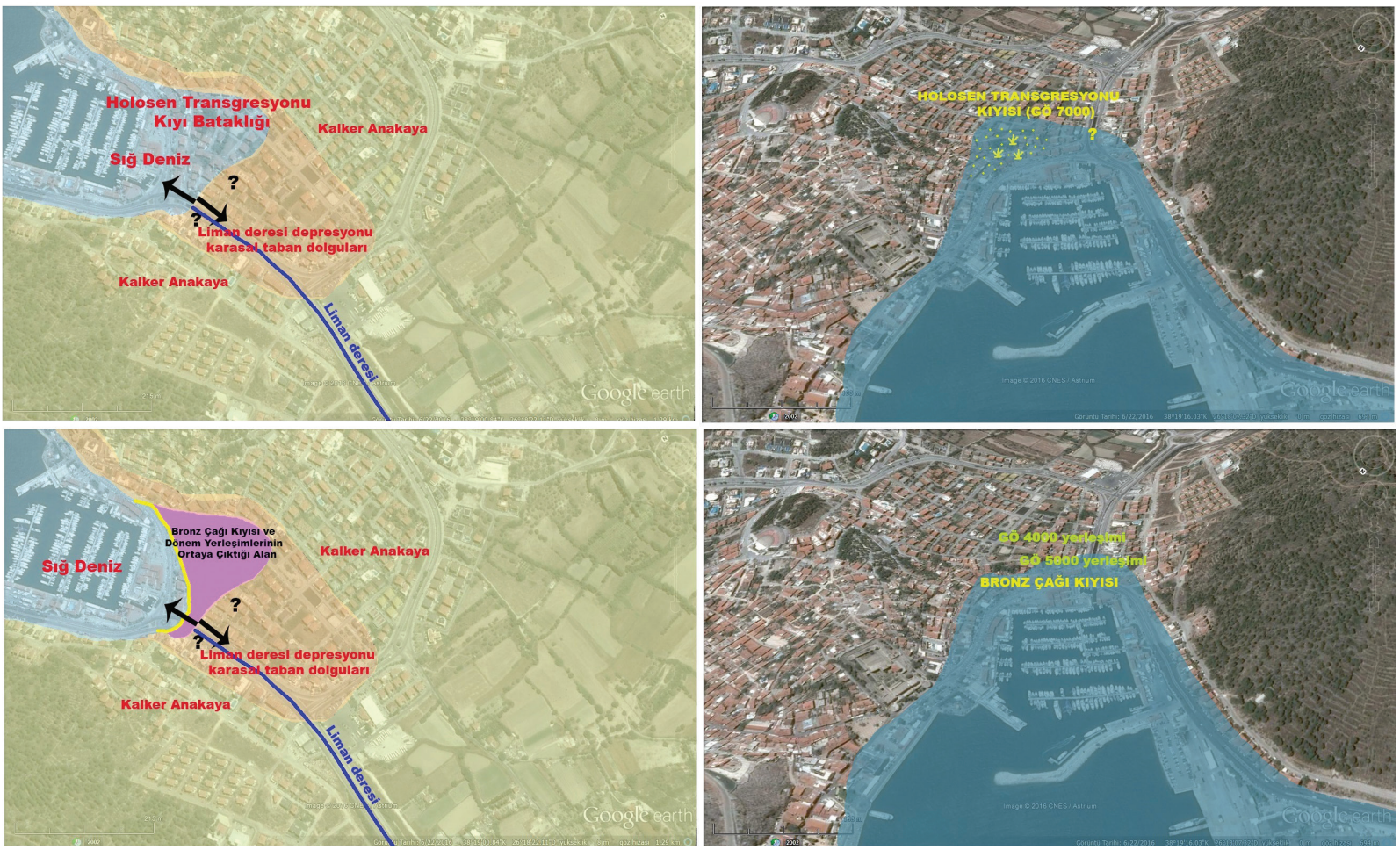

Şekil 14 A - B. Liman deresi vadisi ve Bağlararası çevresinin Holosen transgresyonu ile oluşan kıyısı (A); Liman deresi vadisi ve Bağlararası çevresinin Bronz (Tunç) Çă̆ı Kıyısı (B).

Figure 14 A - B. Shoreline position with the Holocene transgression (A); Bronze Age shore of the Liman stream valley and Bağlararası (B).

Tephra katmanı erken Minos 1A katmanının üzerine gelmektedir. $\mathrm{Bu}$ kültürel stratigrafik konumu GÖ 1640 civarına tarihlenen Santorini patlaması ile uyumludur. Bu bilgilere göre tephra örneklerinin element analizleri ve arkeolojik katman yaşı Minoan patlamasının sunucu olduğunu doğrulamaktadır. Ancak küllerin içinde bulunan daha kaba kül parçalarının farklı element analiz sonucu vermesi ikinci bir külün var olup olmadığ1 sorusunu gündeme getirmiştir. Bu konu halen daha detaylı bir şekilde araştırılmaktadır. ÇB-07, ÇB05, ÇB-09 ve ÇB-01 sondajlarında tephra katmanı bulunmuştur. Tephranın biriktiği yüzey MÖ 1640 y1l öncesine ait k1y1 düzlügünün yüzeyini vermektedir (Şekil 13). Diğer bir değişle Minoan patlaması sırasındaki kıyı düzlüğü yüzeyidir. $\mathrm{Bu}$ süreçte Bağlararası çevresi kıyı bataklığı halini almıştır. $\mathrm{Bu}$ bataklığın üzerindeki katmanda bulunan izlere göre, Bağlararası'nda ilk yerleşim Bronz Çağı regresyonu ile karalaşarak ortaya çıkan bugünkü yüzeyden 4-4,5 m derindeki (deniz seviyesinden 2-2,5 m aşağıda) bölümde var olan eski bir yüzeyde başlamıştır (Şekil 14B). Yapılan kazı çalışmalarına göre antik yerleşim Minos kültürüne ait önemli izler taşımaktadır ve Bronz Çă̆ı'na aittir. Her iki yerleşime ait kültür katmanı yaklaşık 4 m kalınlığındadır. (Şekil 13). Bronz Çağ1 yerleşiminde Erken Minos 1a tabakasının üzerinde yaklaşık MÖ 1640-1650 yıllarına isabet eden Santorini'nin Minoan patlamasina ait kül tabakasına ulaşılmıştır. Bu küller dört sondajda takip edilmiş ve MÖ 1640'lü yıllara ait kıyı düzlügüünün yüzeyi belirlenmiştir. $\mathrm{Bu}$ yüzeyin depresyon geneline yayılabilmesi için Liman deresi kenarları boyunca ve kazı alanlarının güney kesiminde yeni sondajlar yapılması planlanmıştır. 
Ancak Çeşme Bağlararası mevkii turistik bir alanın içinde kaldığı için sondaj yapmak için uygun yer sayısı oldukça azdır. Bunun yanında, Bağlararası mevkiinin güney ve kuzey kesiminde Holosen transgresyonun sokulduğu kesim ve günümüzden 7000 y1l önceki kıy1 belirlenememiştir. Bu sorunun da cevaplanabilmesi için kazı alanındaki çalışmaların 2017 Eylül ayından sonra biteceği de dikkate alınarak Ağustos-Eylül aylarında yeni sondajlar yapilacaktır. $\mathrm{Bu}$ sondajlardan alınacak örneklerin analizleri alandaki bilgileri ve yorumları tekrar değerlendirme firsatı sunacaktır.

\section{EXTENDED SUMMARY}

Geography is a science that studies the interactions between humankind and their environment. Cultural development of societies has always been influenced by their geographical environs. Archaeology is the study of past cultures through analysis of physical remains to understand something about the culture of the people. At the present day, contributions from various disciplines are used in archeology. These contributions are mainly on the research and interpretation of geographical environment of ancient populations. The aim of this paper is to report on the changes of geographical environment of the West Anatolian coasts of Turkey during the late Holocene, by using results from our research focusing on ancient settlements. Sedimentological and paleontological analyses were performed on the samples derived from core drillings on the alluvial plains, and characteristics of the changing environmental is determined. The sea level, which was about -130 $m$ during the last glacial period, rose nearly to the present level in the Mid-Holocene and formed bays and gulfs on the mouths of rivers. By the end of rapid sea-level rise in the Mid-Holocene, the bays and gulfs started to be filled up by alluvial deposits and the coastlines prograde. Thus, the ancient harbors which had been established on the coasts of former bays in the mouths of big rivers, silted up gradually and lost their importance. Our paleogeographical and geoarchaeological research on some of such archaeological sites, contributed valuable interpretations to understand relation between geographical changes and cultural development. Geoarcheological and paleogeographical research makes a great contribution to archaeology. This is also important to comprehend the future changes of geographical environment.

The Aegean coasts of the Anatolia have appropriate geographical conditions during the historical ages and have emerged as suitable places for settlement. Significant environmental changes happened in the surroundings of settlements established along the coasts, depending on rising of sea level (from $-130 \mathrm{~m}$ drop at last Glacial Maximum). The sea intruded towards the former river valleys forming bays and gulfs until Middle Holocene. In time, alluvial materials filled bays and gulfs, and as a result, the coast line started to advance towards the sea. During these periods, settlements which were established as a harbor cities, have been gradually left backshore and have loosen their values where the majority of them have been abandoned. It was understood that $2^{\text {nd }}$ and $3^{\text {rd }}$ millennium $B C$ settlements of the Bronze Age and natural environment was different from present. Çeşme Bağlararası plain is a NW-SE direction tectonic depression that was shaped by filled alluvium of the Liman stream and also a thick colluvium (Figure 1, 3). Liman stream, which has a very small basin filled the shallow shore basin is 500 meters in width and 600 meters in length extending from the bus station of Çeşme Town to recent harbor towards to the NW. The traces of the environmental changes are hidden within the alluvium filling of this depression. Core drillings were done in Bağlararast alluvial plain to determine the paleogeographical-geoarchaeological features of surroundings of the mound in order to detect the changes in coast line and sea level, in order 
to answer archaeological questions. 10 core drillings carried out at the September 2016 in surrounding of the Bağlararası mound (Figure 3). Grain size, hydrometer, calcimeter, microfossil and element analysis of the drilling samples has been done. According to results of the core drillings, Holocene stratigraphy of the fill can be identified as; (1) basement clay-sandstone bedrock, (2) Early Holocene transgression (marine) deposits, coastal swamp (Middle Holocene), mound fills (Middle-Late Holocene) and alluvial-colluvial fills (Late Holocene). Starting of $3^{\text {rd }}$ Millennium $B C$ settlement was closer to the coast which is consistent with the Bronze Age regression. Beside this it was determined that the $2^{\text {nd }}$ Millenium settlement was established in inner parts of the coastal plain after regression.

The chemical analysis of a tephra layer, which is found within the cultural fills of the Bronze Age period, correlates well with the tephra emitted from Minoan volcanic eruption of Santorini. This layer is used as a key layer in chronostratigraphic interpretations. (Table 1). This finding correlates well with the $1.5-2 \mathrm{~cm}$ thick volcanic ash layer which was determined above archaeologic remains, containing stones and ceramic samples of Late Minos IA (middle of the $17^{\text {th }}$ century BC.) (Şahoğlu et. al. 2014). According to the stratigraphic position of the ash layer, it is interpreted as tephra emitted during Minoan eruption of Santorini. These ash layers can be used for correlation of for adjacent Aegean and Anatolian archeological sites (Şahoğlu et. al. 2014), but always with the geochemical analysis to avoid discrepancies (such as Nysiros tephra; Kazancr et. al. 2011).

Volcanic ash layer of Minoan is used for both relative dating and supporting environmental evaluations for paleogeography-geoarchaeology of Bağlararast mound and its surroundings. For that reason paleogeographical research for whole Çeşme area and geoarchaeological research for Bağlararası mound are needed. The approach by the core drills it can be reached deeper layers and a new chronostratigraphic evaluation can be made. Thus environmental changes can be carried out and can provide stronger chronostratigraphic base within the alluvial strata of the Çeşme Bağlararast coastal plain, the surface of 1640 BC is determined according to depth and distribution of the Minoan tephra (Figure 13). Similarly, such this relieffor old bottom surface of the lake Gölcük and between Eşen plains old alluvial layers were revealed (Vardar and Öner $2016 a$ and $b$ ).

\section{ORCID}

Serdar Vardar (D) https://orcid.org/0000-0002-8448-9290

Ertuğ Öner (D) https://orcid.org/0000-0002-9712-5277

Rifat Illhan (D) https://orcid.org/0000-0001-8392-9349

\section{DEĞIINILLEN BELGELER}

Brückner, H., Kelterbaum, D., Marunchak, O., Porotov, A., Vött, C., 2010. "The Holocene Sea Level Story since 7500 BP- Lessons from the Eastern Mediterranean, the Black and the Azov Seas", Quaternary International 225 (2), 160-179.

Ankara Üniversitesi Sualtı Arkeolojik Araştırma ve Uygulama Merkezi (ANKÜSAM), 2016, http:// ankusam.ankara.edu.tr/cesme/, 21 Aralık 2016.

Kazancı N., Boyraz S., Özkul M., Alçiçek M.C. , Kadıŏlu Y.K., 2011. Late Holocene terrestrial tephra record at western Anatolia, Turkey: Possible evidence of an explosive eruption outside Santorini in the eastern Mediterranean, Global and Planetary Change 80 (2012) 36-50.

Kayan, İ., 1988. "Late Holocene sea-level changes on the Western Anatolian coast", Palaeogeography, Palaeoclimatology, Palaeoecology 68, (2-4), 205218, Special Issue: Quaternary Coastal Changes. Ed. by P. A. Pirazzoli - D. B. Scott. (A selection of papers presented at the IGCP-200 meetings) Elsevier Science Publishers B. V. Amsterdam. The Netherlands.

Kayan, İ., 1995. "The Troia bay and supposed harbour sites in the Bronze Age", Studia Troica, Band 5., s. 211-235. Philipp von Zabern. 
Kayan, İ., 1996. "Holocene coastal development and archaeology in Turkey", Zeitschrift für Geomorphology. Supplementband 102. Field Methods and Models to Quantify Rapid Coastal Changes. Ed. by D.H. KELLETAT and N.P. PSUTY. p. 37-59. Berlin. Germany. International Geographical Union. Commission on Coastal Systems. Proceedings of the Field Symposium Crete, Greece, April 1994.

Kayan, İ., 1997. “Türkiye'nin Ege ve Akdeniz kıyılarında Deniz Seviyesi ve Kıyı Çizgisi Değişmeleri”, Türkiye Klyıları 97 Konferansı Bildiriler Kitab1, E. Özhan (Editör), s. 735-746. Ankara.

Kayan, İ., 1999. "Holocene stratigraphy and geomorphological evolution of the Aegean coastal plains of Anatolia", The Late Quaternary in the Eastern Mediterranean Region. 1-4 April 1997 Ankara. Proceedings. Quaternary Science Reviews 18 (4-5), 541-548. Elsevier.

Kayan, İ., 2012. "Kuvetarner'de deniz seviyesi değişmeleri”, Kuvaterner Bilimi. (Ed. N. Kazancı, A. Gürbüz. 570 s), Ankara Üniversitesi Yay. No: 350. s. 59-78. Ankara.

Lambeck, K., 1995. "Late Pleistocene and Holocene sea-level change in Greece and south-western Turkey: a separation of eustatic, isostatic and tectonic contributions", Geophys. J. Int., 122, 1022-1044.

MTA 1/500.000 Ölçekli Jeoloji Haritas1, 2017. http:// www.mta.gov.tr/v3.0/sayfalar/hizmetler/doc/ DENIZLI.pdf., 27.07.2017.
Öner, E. 2013. Likya'da Paleocoğrafya ve Jeoarkeoloji Araştırmaları, Ege Üniversitesi Yayınları, Edebiyat Fakültesi Yayın No: 182, 479 s., Ege Üniversitesi Basımevi, Bornova, İzmir.

Öner, E. 2016. "Ege ve Akdeniz kıyılarımızda paleocoğrafya-jeoarkeoloji araştırmaları”, Ege Coğrafya Dergisi 25/1, 51-66.

Şahoğlu, V., Böyükulusoy, Ü.Ç., Erbil, Y.H., Erkanal, H,Tuğcu, İ., 2014. "2012 y1lı Çeşme -Bağlararas1 kaziları”, Anatolia 40, 179-198.

Vardar, S.,Öner,E. 2016a. “Investigation on Distrubution of the Santorini (Thera)Tephra in West Anatolia and Paleogeographical-Geoarchaeological Features of the Çeşme-Bağlararası mound", Proceedings of III. International Çeşme-Chios History, Culture and Tourism Symposium. 3-4 Kasım, 78-96, Çeşme-İzmir, Turkey.

Vardar S., Öner, E., 2016b. "Batı ve Güneybatı Anadolu'nun Paleocoğrafyası ve Jeoarkeolojisinde Santorini (Thera) Küllerinin Önemi”, A.Ü. Türkiye Coğrafyası Araştırma ve Uygulama Merkezi Cografi Bilimler Dergisi, Cilt 14, Say1 1,15-37.

Waelbroeck, C., Labeyrie, L., Michel, E., Duplessy, J.C., Mcmanus, J.F., Lambeck, K., Balbon, E., Labracherie M., 2002. "Sea-Level and Deep Water Temperature Changes Derived from Benthic Foraminifera Isotopic Records", Quaternary Science Reviews 21, 295-305. 